\title{
Second Messengers Involved in the Mechanism of Action of Bradykinin in Sensory Neurons in Culture
}

\author{
Gillian M. Burgess, lan Mullaney, ${ }^{a}$ Mary McNeill, Philip M. Dunn, and Humphrey P. Rang \\ The Sandoz Institute for Medical Research, London WC1E 6BN, United Kingdom
}

\begin{abstract}
Application of bradykinin to neonatal rat dorsal root ganglion neurons caused a depolarization associated with an inward current and an increase in membrane conductance that was probably due to the opening of sodium channels. No hyperpolarization or outward current was detected. In addition, bradykinin increased the rate of ${ }^{45} \mathrm{Ca}$ uptake into the neurons by a mechanism that was blocked by the dihydropyridine calcium channel antagonist nifedipine. Direct activation of protein kinase C (PKC) with phorbol esters mimicked the ability of bradykinin to depolarize the neurons and to increase the rate of ${ }^{45} \mathrm{Ca}$ uptake. Down-regulation of PKC by prolonged treatment with phorbol esters and treatment of the cells with staurosporine, which inhibits PKC, blocked both bradykinin- and phorbol ester-induced ${ }^{45} \mathrm{Ca}$ influx, and substantially reduced the proportion of cells that gave electrophysiological responses to either agent.

Bradykinin also activated polyphosphoinositidase $C$ in the dorsal root ganglion neurons, elevating levels of inositol(1,4,5)-trisphosphate and 1,2, diacylglycerol, an endogenous activator of PKC. It is suggested, therefore, that PKC may mediate some of the effects of bradykinin in sensory neurons.
\end{abstract}

Bradykinin (Bk) is a potent pain-producing peptide, formed at sites of injury, that stimulates the peripheral terminals of sensory afferent fibers, including the polymodal nociceptors (Erdos, 1979). Much information about activation of nociceptors has come from studies of sensory fibers in vivo (e.g., Beck and Handwerker, 1974; Mense and Schmidt, 1974; Franze and Mense, 1975), but as sensory nerve terminals are small and inaccessible structures, there is little information about the biochemical events underlying their activation by chemical or other types of stimuli. Electrophysiological studies on nodose ganglion cells (Higashi et al., 1982; Weinreich, 1986) have suggested that Bk may exert an excitatory effect by reducing potassium conductance, but only in neuroblastoma-glioma hybrid cells (Higashida and Brown, 1986; Tertoolen et al., 1987; Brown and Higashida, 1988) has the biochemical basis for this type of membrane effect been studied. The use of primary cultures of sensory neurons allows both the electrophysiological and biochemical properties of these cells to be examined in detail (Dichter and Fischbach, 1977;

\footnotetext{
Received Dec. 19, 1988; revised Mar. 1, 1989; accepted Mar. 2, 1989.

We thank Prof D. H. Jenkinson and Dr. S. J. Bevan for helpful comments and advice during the preparation of the manuscript.

Correspondence should be addressed to Gillian M. Burgess, Sandoz Institute for Medical Research, 5 Gower Place, London WC1E 6BN, United Kingdom.

a Present address: The Department of Biochemistry, The University of Glasgow, Glasgow, UK

Copyright (C) 1989 Society for Neuroscience $0270-6474 / 89 / 093314-12 \$ 02.00 / 0$
}

Baccaglini and Hogan, 1983; Miller, 1987; Burgess et al., 1988; Lindsay and Rang, 1988; Thayer et al., 1988), and we have taken advantage of this to try to elucidate the mechanism of action of Bk on rat dorsal root ganglion (DRG) ncurons.

Our main aim was to determine the relationship, if any, between the biochemical events initiated by Bk in these neurons and the electrophysiological excitation. We have found, as recently reported by Thayer et al. (1988), that Bk, as in many other cells, causes an elevation of inositol $(1,4,5)$ trisphosphate [Ins $\left.(1,4,5) \mathrm{P}_{3}\right]$ and of 1,2 ,diacylglycerol $(1,2, \mathrm{DAG})$. There was also an increase in arachidonic acid. The membrane response, which occurred independently of extracellular calcium, consisted of an inward (depolarizing) current associated with increased membrane conductance.

There is much evidence that protein kinase $\mathrm{C}(\mathrm{PKC})$ is important in controlling various aspects of neuronal function, modulating the activity of several ion channels, and regulating neurotransmitter release (see Kaczmarek, 1987; Miller, 1987), and it has recently been suggested that PKC might play a role in the excitation of polymodal nociceptors. Activation of PKC leads to the depolarization of the $C$ fibers of the rat vagus (Rang and Ritchie, 1988) and excitation of the capsaicin-sensitive C-fibers in the tail of the neonatal rat spinal cord and tail preparation (Bettaney et al., 1988; Dray et al., 1988). As the Bk-mediated increase in 1,2,DAG (or arachidonic acid or both, see Nishizuka, 1988 ) is likely to activate PKC in the DRG neurons, the possibility that the membrane effects of Bk might be mediated by PKC was tested by comparing the effects of phorbol esters, which activate PKC directly, with those of Bk.

It was found that the electrophysiological response, as well as an associated increase in ${ }^{45} \mathrm{Ca}$ uptake, could be mimicked by phorbol esters and by a diacylglycerol analog, and inhibited both by down-regulation of PKC and by staurosporine, a PKC inhibitor (see Tamaoki et al., 1986). This supports the possibility that $\mathrm{PKC}$ activation may play a role in the process whereby $\mathrm{Bk}$ causes excitation of these neurons.

\section{Materials and Methods}

Culture of DRG neurons. DRG neurons from neonatal rats were prepared as described previously (Baccaglini and Hogan, 1983; Wood et al., 1988). Dissociated cells were plated on poly-D-ornithine-coated petri dishes for $1 \mathrm{hr}$. During this period, the non-neuronal cells from the ganglia became firmly attached to the dish, and the neuronal cells could be washed off to give a suspension consisting mainly of neurons. The non-neuronal cells, which remained attached to the dish, could be maintained in culture and used as controls for biochemical experiments. The enriched neuronal preparation was plated onto coverslips coated with poly-D-ornithine and laminin in Hams F-14 medium containing: $\mathrm{NaHCO}_{3}, 14.0 \mathrm{~mm}$; glutamine, $1.0 \mathrm{~mm}$; penicillin, $100 \mu \mathrm{g} / \mathrm{ml}$; streptomycin, 100 units/ml; horse serum, $10 \%$; nerve growth factor, $5 \mu \mathrm{g} /$ $\mathrm{ml}$; and cytosine arabinoside, $10 \mu \mathrm{M}$. After about $3 \mathrm{~d}$, when the non- 
neuronal cells represented only $5 \%$ of the cells, the cytosine arabinoside was removed and the DRG neurons grown for a further 5-7 d before use. For biochemical experiments about $90 \%$ of the cells in the cultures were neurons. Non-neuronal cells were grown in the same medium but without nerve growth factor or cytosine arabinoside.

Electrophysiology. DRG neurons were plated at low density (10005000 cells) on coverslips that were placed in a $0.5 \mathrm{ml}$ chamber on the stage of an inverted phase-contrast microscope. The chamber was perfused with physiological salt solution containing (mM) NaCl, 154.0; $\mathrm{NaHCO}_{3}, 1.8 ; \mathrm{KCl}, 5.6 ; \mathrm{CaCl}_{2}, 2.0$; glucose, 5.6; HEPES, 10.0 (buffered to $\mathrm{pH} 7.3$ with $6.5 \mathrm{mM} \mathrm{NaOH})$ at $2 \mathrm{ml} / \mathrm{min}$. Low-sodium $(8.3 \mathrm{~mm})$ Locke was made by equimolar replacement of $\mathrm{NaCl}$ with $N$-methyl glucamine chloride. The temperature was maintained at $30-32^{\circ} \mathrm{C}$. Recordings were made by the tight-seal, whole-cell voltage-clamp technique (Hamill et al., 1981), with fire-polished pipettes of resistance 2$7 \mathrm{M} \Omega$ attached to the head stage of an Axopatch recording amplifier (Axon Instruments Inc.). For most experiments, the recording pipettes were filled with a medium of the following composition (in $\mathrm{mM}$ ): $\mathrm{KCl}$, $140 ; \mathrm{MgCl}_{2}, 1$; Mg-ATP, 1; K-HEPES, 10; EGTA, $10 ; \mathrm{CaCl}_{2}, 5.2$ (calculated free calcium concentration, $100 \mathrm{nM}$ ), $\mathrm{pH} 7.3$; variations are indicated under Results. Drugs, made up in physiological salt solution, were applied by pressure ejection from pipettes of about $5 \mu \mathrm{m}$ diameter placed about 10-20 $\mu \mathrm{m}$ from the cell body. The cells normally had resting potentials of -50 to $-70 \mathrm{mV}$ and gave overshooting action potentials in response to depolarizing current pulses. In most experiments the membrane potential was clamped to $-80 \mathrm{mV}$, with alternating jumps to -100 and $-60 \mathrm{mV}$ repeated every $3 \mathrm{sec}$; the amplitude of the associated current deflections indicated changes in membrane conductance.

Measurement of inositol phosphate formation. DRG neurons $(30,000$ cells/coverslip) were incubated for $20 \mathrm{hr}$ in Eagle's medium with Earle's salts that contained $m y o-2-\left[{ }^{3} \mathrm{H}\right]$-inositol $(50 \mu \mathrm{Ci} / \mathrm{ml})$. At the end of this period, the labeled medium was removed, and the cells were washed and placed in nonradioactive HEPES-buffered Dulbecco's modified Eagle's medium (DMEM) for the duration of the experiment. Cells were exposed to drugs by dipping the coverslips into $10 \mathrm{ml}$ of control or drug-containing DMEM at $37^{\circ} \mathrm{C}$ for the times indicated in individual experiments. The reactions were terminated by plunging the coverslips into $2 \mathrm{ml}$ of ice-cold $10 \%$ trichloroacetic acid (TCA). The ${ }^{3} \mathrm{H}$-inositol phosphates were extracted for $20 \mathrm{~min}$, and the TCA was removed by extracting 5 times in 5 vol of diethyl ether. The samples were then neutralized with $\mathrm{NH}_{4} \mathrm{OH}$.

The ${ }^{3} \mathrm{H}$-inositol phosphates were separated either by anion-exchange chromatography on Dowex columns (formate form) as described previously (Berridge, 1983) or, in some cases, by high-pressure liquid chromatography (HPLC). Where Dowex columns were used, the fraction referred to as inositol trisphosphate $\left(\mathrm{InsP}_{3}\right)$ was eluted with $0.75 \mathrm{M}$ ammonium formate in $0.1 \mathrm{M}$ formic acid.

Separations by HPLC were done on a Whatman Partisil 10 SAX anion-exchange column with modifications of ammonium formate/ phosphate ( $\mathrm{pH}$ 3.7) gradients as described by Burgess et al. (1985) and Heslop et al. (1985). All the inositol phosphates except inositol tetrakisphosphate ( $\mathrm{InsP}_{4}$ ) were eluted by a nonlinear gradient (convex, no. 4 on a Waters model 660 gradient programmer) at $1.2 \mathrm{ml} / \mathrm{min}$, increasing from 0 to $1 \mathrm{M}$ ammonium formate in $40 \mathrm{~min}$. The $1 \mathrm{M}$ buffer was run for a further $5 \mathrm{~min}$, and then the concentration was further increased over 5 min via a linear gradient to $1.7 \mathrm{~m}$. This final solution was run for a further $20 \mathrm{~min}$ to elute Ins $\mathrm{P}_{4} \cdot{ }^{3} \mathrm{H}$-Ins $(1,4,5) \mathrm{P}_{3}$ from $\mathrm{DRG}$ neurons was identified by comparison with either ${ }^{32} \mathrm{P}$-Ins $(1,4,5) \mathrm{P}_{3}$ (prepared as described by Downes et al., 1982) or with a ${ }^{3} \mathrm{H}-\operatorname{Ins}(1,4,5) \mathrm{P}_{3}$ standard from Amersham. ${ }^{3} \mathrm{H}$-Ins $\mathrm{P}_{4}$ was identified by comparison with a ${ }^{3} \mathrm{H}$ Ins $(1,3,4,5) P_{4}$ standard from Amersham, although the material from the DRG neurons was not necessarily this isomer. A peak eluting immediately prior to $\operatorname{Ins}(1,4,5) \mathrm{P}_{3}$ was tentatively identified as ${ }^{3} \mathrm{H}$ Ins $(1,3,4) \mathrm{P}_{3}$ on the basis that material obtained from several other tissues that elutes in this position has been chemically determined to be Ins $(1,3,4) \mathrm{P}_{3}$ (Irvine et al., 1984b; Burgess et al., 1985). For each experiment the radioactivity in the inositol phosphates (corrected for losses during extraction and separation) was expressed as a percentage of the total lipid radioactivity, which was almost all associated with phosphatidylinositol.

Measurement of diacylglycerol formation and arachidonic acid release. DRG neurons, plated at $50,000 /$ coverslip, were loaded with ${ }^{14} \mathrm{C}$-arachidonic acid $(2 \mu \mathrm{Ci} / \mathrm{ml})$ for $90 \mathrm{~min}$ at $37^{\circ} \mathrm{C}$ in bicarbonate buffered DMEM. After this loading period, the cells were washed 5 times with HEPES- buffered DMEM to remove unincorporated radioactive material. Cells were exposed to drugs by dipping the coverslips into $10 \mathrm{ml}$ of control or drug-containing HEPES-buffered DMEM $\left(37^{\circ} \mathrm{C}\right)$ for the times indicated in individual experiments. The incubation was terminated by plunging the coverslips into $1 \mathrm{ml}$ ice-cold chloroform/methanol $(1: 2)$. Lipids were then extracted for $15 \mathrm{~min}$, after which $0.4 \mathrm{ml}$ chloroform and $0.4 \mathrm{ml} \mathrm{H}_{2} \mathrm{O}$ were added to each tube. The tubes were vortexed and extracted for a further $10 \mathrm{~min}$, after which they were centrifuged for 10 min and the organic layer removed. The aqueous phase was reextracted with $0.8 \mathrm{ml}$ chloroform and the second organic phase was combined with the first and dried under nitrogen. The samples were then redissolved and spotted onto thin-layer chromatography (TLC) plates along with authentic 1 -stearyl-2-[ $\left[{ }^{14} \mathrm{C}\right]$-arachidonyl-glycerol and ${ }^{14} \mathrm{C}$-arachidonic acid. Lipids and free fatty acids were separated by developing the plates in one dimension in benzene/diethyl ether/ethyl acetate/acetic acid $(80: 10: 10: 0.2$ by volume) plus $0.01 \%$ butylated hydroxytoluene until the solvent was $16 \mathrm{~cm}$ from origin (Storry and Tuckley, 1967). ${ }^{14} \mathrm{C}$-labeled lipids were visualized by autoradiography following exposure of the TLC plates to Kodak X-OMAT film for $14 \mathrm{~d}$. Quantitation of the radioactivity in individual spots was achieved by scraping the relevant regions of the TLC plates and counting in a liquid scintillation counter. ${ }^{14} \mathrm{C}-1,2, \mathrm{DAG}$ and ${ }^{14} \mathrm{C}$-arachidonic acid from DRG neurons was expressed as a percentage of the total radioactivity in each sample.

Measurement of the initial ${ }^{45} \mathrm{Ca}$ uptake rate. DRG neurons plated at $50,000 /$ coverslip were incubated with or without drug for $30 \mathrm{sec}$ at $37^{\circ} \mathrm{C}$ in HEPES-buffered DMEM without added calcium. The cells were then incubated with the same medium but containing $2 \mu \mathrm{Ci} / \mathrm{ml}^{45} \mathrm{Ca}$ for either $5,10,15$, or $20 \mathrm{sec}$. (The calcium concentration of the medium was determined by atomic absorption spectroscopy to be about $10 \mu \mathrm{M}$.) The coverslips were then immediately dipped into 3 successive $10 \mathrm{ml}$ washes of ice-cold DMEM containing $1.8 \mathrm{mM} \mathrm{CaCl}_{2}$ and $100 \mu \mathrm{M} \mathrm{LaCl}_{3}$ and placed in a scintillation vial containing $225 \mu \mathrm{l}$ of $1 \mathrm{M} \mathrm{NaOH}$. After 4 $\mathrm{hr}$, a sample was removed for protein determination and the radioactivity associated with the cells determined. Coverslips without cells were treated in an identical fashion and the radioactivity in these blanks (about 10\% of the radioactivity in the presence of cells) was subtracted from the cell samples. The initial rate of uptake of the ${ }^{45} \mathrm{Ca}$ was expressed as $\mathrm{pmol}{ }^{45} \mathrm{Ca} / \mathrm{min} / \mathrm{mg}$ protein.

$P K C$-associated immunoreactivity. $\mathrm{PKC}$ immunoreactivity was measured using MC5, a monoclonal antibody that recognizes the $\alpha$ and $\beta$ forms of PKC, following the protocol described by Amersham.

Values given in the Results section represent means \pm SEM.

Materials. All radiochemicals were obtained from Amcrsham. Tissue culture materials were obtained from Gibco, except for collagenase and trypsin (Worthington), DNAase and trypsin inhibitor (Sigma), and nerve growth factor, which was a gift from Dr. R. Lindsay. MC5 used in initial experiments was a generous gift from Dr. P Parker and was later obtained from Amersham. Other sources were as follows: Fluka, staurosporine; Sigma, nifedipine, mepacrine, and all phorbol esters; Avanti Polar Lipids, oleoyl-acetyl-glycerol (OAG); Porton Down, U.K., pertussis toxin; Wellcome Research Laboratories, BW7755C. Bk was obtained from Sandoz, Basle, and other peptides were obtained from Nova Biochem.

\section{Results}

\section{Electrophysiological response to $\mathrm{Bk}$}

The majority of the neurons in culture were of a similar morphological type, with phase-bright, roughly spherical cell bodies $15-30 \mu \mathrm{m}$ in diameter and an extensive neurite tree. These cells gave action potentials of varying duration in the range of 2-10 msec, usually with an obvious hump on the falling phase. The remaining cells were larger (up to $70 \mu \mathrm{m}$ ), and their action potentials were short (usually 1-2 msec), with no hump on the falling phase. Previous studies of DRG and nodose ganglia from various species have demonstrated the existence of 2 major neuronal subtypes, namely, A-cells, which have myelinated, fastconducting axons and short action potential durations, and $C$-cells, which have nonmyelinated, slowly conducting axons and action potentials with a distinct shoulder on the falling phase (Gallego and Eyzaguirre, 1978; Yoshida et al., 1978; Gorke and Pierau, 1980; Harper and Lawson, 1985a, b; Ikeda et al., 1986). 

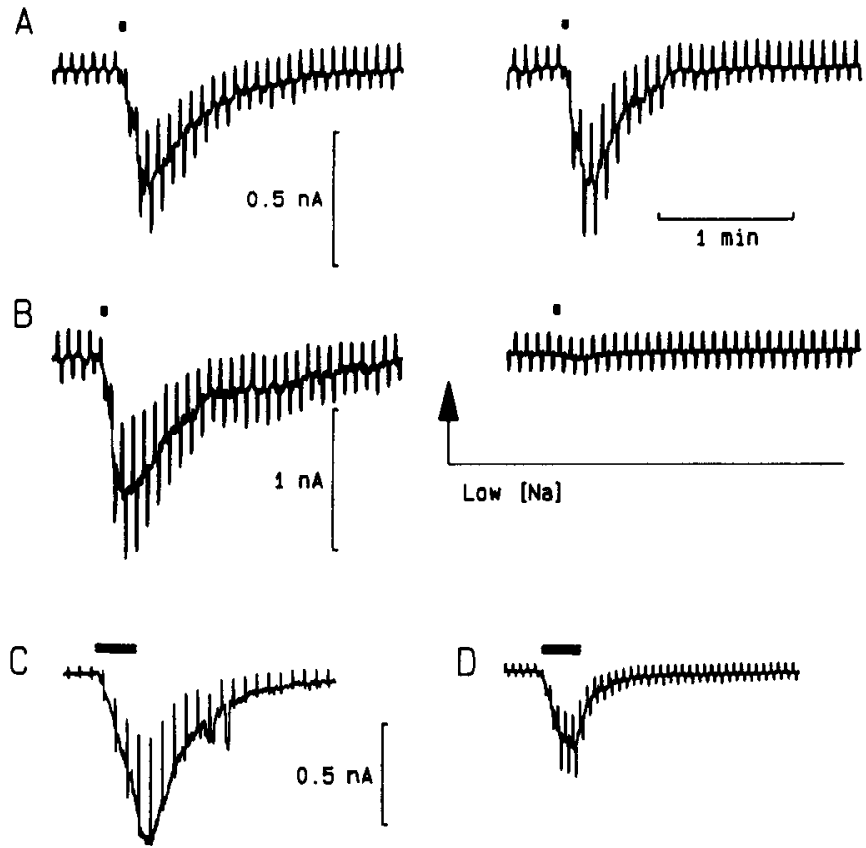

Ca-free

K-aspartate

in pipette

Figure 1. Membrane response of DRG neurons to Bk recorded by whole-cell voltage clamp. The records show membrane current, inward current downward. The holding potential was $-80 \mathrm{mV}$ in all records, with $400 \mathrm{msec}$ excursions alternatively to -60 and $-100 \mathrm{mV}$, resulting in upward and downward deflections of the current trace. (In $C$, the excursions were from -80 to $-40 \mathrm{mV}$.) $A$, Consecutive responses to Bk $(1 \mu \mathrm{M})$ applied for $1 \mathrm{sec}$ at bar. The interval between the responses was $10 \mathrm{~min}$. This cell was unusual in showing little or no desensitization. $B$. As in $A$, in a different cell from the same culture. The solution was changed to one containing $8.3 \mathrm{~mm} \mathrm{Na} \mathrm{Na}^{+} 3 \mathrm{~min}$ after the first response. $C$, Response to $\mathrm{Bk}(1 \mu \mathrm{M}$ for $10 \mathrm{sec}$ at bar $)$ in a solution containing no added $\mathrm{Ca}^{2+} . D$, As $C$, in normal Locke; pipette solution contained 140 $\mathrm{mM} \mathrm{K}$-aspartate in place of $\mathrm{KCl}$.

Bk had no effect on A cells. Application of Bk (1 $\mu \mathrm{M}$ for 1-2 sec) produced, in $32 \%(107 / 335)$ of the C cells tested, an inward current at the holding potential of $-80 \mathrm{mV}$, associated with an increase in membrane conductance (Fig. 1). In the responding cells, the mean amplitude of this inward current at $-80 \mathrm{mV}$ was $0.54 \pm 0.06 \mathrm{nA}(n=107)$. The inward current response developed within a few seconds, reaching a peak at $17 \pm 2 \mathrm{sec}$ $(n=107)$, and declined within $30 \mathrm{sec}$ of the end of the puff.

In a few cultures the response to Bk showed different patterns; namely, a much slower inward current, again associated with an increase in membrane conductance, lasting up to $15 \mathrm{~min}$, or

\section{Table 1. Effect of intracellular free $\mathrm{Ca}^{2+}$ and tetrodotoxin on the} electrophysiological response to $\mathrm{BK}$

\begin{tabular}{clcl}
$\begin{array}{c}{\left[\mathrm{Ca}^{2+}\right]_{i}} \\
(\mathrm{nM})\end{array}$ & $\begin{array}{l}\text { TTX } \\
(\mu \mathrm{M})\end{array}$ & $\begin{array}{l}\text { Cells responding/ } \\
\text { cells tested }\end{array}$ & Mean response (nA) \\
\hline 0 & 0 & $21 / 50$ & $0.31 \pm 0.09(21)$ \\
0 & 1 & $15 / 40$ & $0.44 \pm 0.16(15)$ \\
100 & 0 & $107 / 335$ & $0.54 \pm 0.06(107)$
\end{tabular}

The intracellular solution contained $10 \mathrm{~mm}$ EGTA and either no added calcium or $5.2 \mathrm{mM} \mathrm{CaCl}_{2}$ to give an estimated free $\left[\mathrm{Ca}^{2+}\right]$ of $100 \mathrm{nM}$. The inward current responses to $1 \mu \mathrm{M} \mathrm{Bk}$ were measured at $-80 \mathrm{mV}$ holding potential.

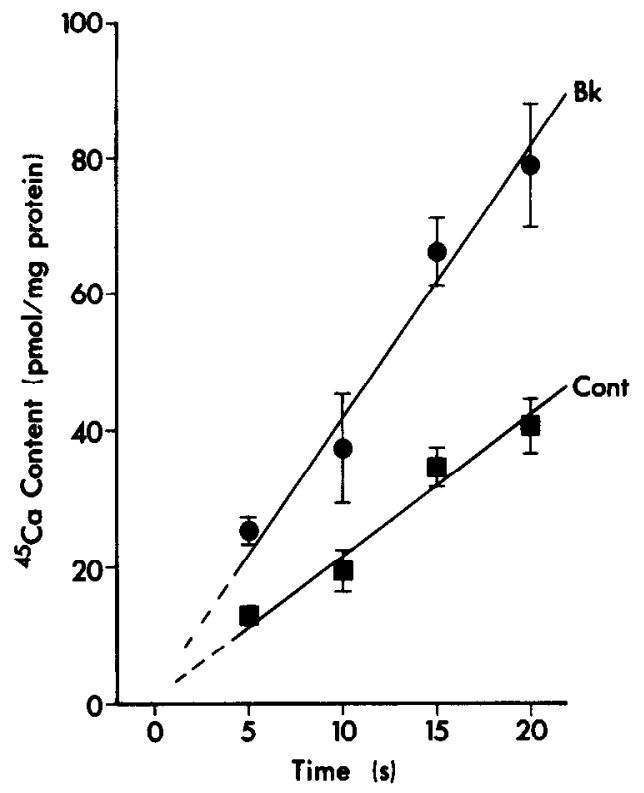

Figure 2. Effect of Bk on the rate of uptakc of ${ }^{45} \mathrm{Ca}$ into DRG neurons. Time course of ${ }^{45} \mathrm{Ca}$ uptake in absence and presence of $\mathrm{Bk}(100 \mathrm{nM})$. DRG neurons were incubated with or without $\mathrm{Bk}$ for $30 \mathrm{sec}$, then transferred to the same medium containing ${ }^{45} \mathrm{Ca}$ for the times indicated. The ${ }^{45} \mathrm{Ca}$ content of the cells has been expressed as $\mathrm{pmol}^{45} \mathrm{Ca} / \mathrm{mg}$ protein. Bars indicate SEM of at least 4 experiments.

a burst of fast inward currents (presumably action potentials originating in unclamped neurites), without any maintained inward current or conductance change recorded at the soma. These have not been included in the analysis.

Bk did not produce an outward current response, even when the membrane potential was held at $-40 \mathrm{mV}$; this is in contrast to studies on NG108-15 cells, in which a major component of the response to $\mathrm{Bk}$ is an increase in a $\mathrm{Ca}^{2+}$-activated $\mathrm{K}^{+}$conductance (Brown and Higashida, 1988).

The inward current response to Bk showed marked desensitization, and a second application, up to $30 \mathrm{~min}$ later, usually evoked little or no response. This made it difficult to study the pharmacology or the ionic dependence of the response in detail, as controls on the same cell were seldom possible. Occasionally, cells were encountered that showed little desensitization (see Fig. $1 A$, in which an interval of 10 min separated the first and second responses), allowing paired observations to be made.

The ionic dependence of the fast inward current response has been examined, and the following results obtained:

1. The response was abolished, or greatly reduced, when external sodium was reduced to $8.3 \mathrm{~mm}$. In 3 experiments, $10 / 19$ cells responded to $\mathrm{Bk}$ in normal Locke (mean current amplitude, $0.18 \pm 0.03 \mathrm{nA}$ ) compared with $0 / 16$ in low sodium. In one experiment, shown in Figure 1, in a culture showing less than the normal degree of desensitization, a second application of $\mathrm{Bk}$ to the same cell, $10 \mathrm{~min}$ after the first, gave a mean response that was $60 \pm 18 \%(n=8)$ of the first (Fig. 1A). If low-sodium solution was applied before the second test, the second response was only $4 \pm 2 \%(n=3)$ of the first (Fig. $1 B)$, suggesting that most of the inward current was carried by $\mathrm{Na}^{+}$. Addition of tetrodotoxin (TTX, $1 \mu \mathrm{M}$ ) to the medium did not affect the response to $\mathrm{Bk}$, even though the action potential was blocked or greatly attenuated (Table 1).

2. Omission of extracellular calcium did not prevent or ob- 

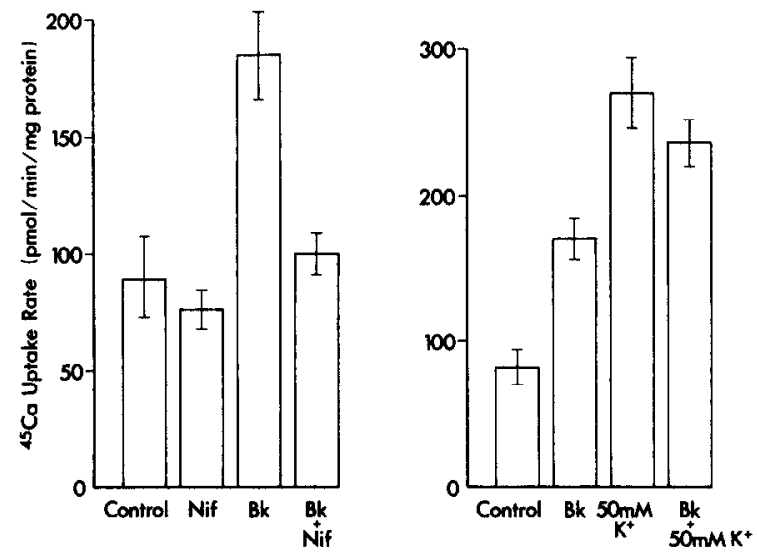

Figure 3. Effect of nifedipine and high $\mathrm{K}^{+}$on the $\mathrm{Bk}$-induced increase in the rate of ${ }^{45} \mathrm{Ca}$ uptake into DRG neurons. Protocol as in Figure 2; the cells were incubated in the ${ }^{45} \mathrm{Ca}$ for $20 \mathrm{sec}$. Left, Incubation of DRG neurons with nifedipine ( $1 \mu \mathrm{M}, N i f)$ for $2 \mathrm{~min}$ prior to and during measurement of ${ }^{45} \mathrm{Ca}$ uptake, blocked the effect of $300 \mathrm{nM} \mathrm{Bk}$. Right, Depolarization with $50 \mathrm{~nm} \mathrm{~K}{ }^{+}$(replacing $\mathrm{Na}^{+}$) also increased the rate of uptake of ${ }^{45} \mathrm{Ca}$ into the DRG neurons. In the presence of $50 \mathrm{mM} \mathrm{K}{ }^{+} \mathrm{Bk}$ (300 nM) no longer increased ${ }^{45} \mathrm{Ca}$ uptake. Bars indicate SEM of 3 experiments.

viously reduce the response to $\mathrm{Bk}$ (Fig. 1C). Omission of calcium from the pipette solution, which reduced $\left[\mathrm{Ca}^{2+}\right]_{i}$ from $100 \mathrm{nM}$ to zero, slightly reduced the response (Table 1).

3. Replacement of $\mathrm{KCl}$ in the pipette with $\mathrm{K}$-aspartate did not prevent the Bk response (Fig. $1 D$ ), suggesting that $\mathrm{Cl}^{-}$was not a major charge carrier for the inward current.

\section{Effect of $\mathrm{Bk}$ on the rate of uptake of ${ }^{45} \mathrm{Ca}$}

$\mathrm{Bk}$ caused an increase in the rate of ${ }^{45} \mathrm{Ca}$ uptake into DRG neurons (Fig 2). Addition of Bk (100 nM) $30 \mathrm{sec}$ before and during exposure of the cells to ${ }^{45} \mathrm{Ca}$ approximately doubled the initial rate of uptake of ${ }^{45} \mathrm{Ca}$. The concentration-effect relationship for this increase $\left(\mathrm{EC}_{50}=6 \mathrm{nM}\right)$ is shown in Figure 5. The increase was prevented by nifedipine ( 0.3 or $1 \mu \mathrm{M}$; Fig. 3, left) and by cadmium $(100 \mu \mathrm{M})$. Depolarization of the cell with $\mathrm{K}^{+}$ (50 mM) also increased the rate of ${ }^{45} \mathrm{Ca}$ uptake (Fig. 3, right). The effects of maximal concentrations of $\mathrm{Bk}(300 \mathrm{nM})$ and $\mathrm{K}^{+}$ $(50 \mathrm{mM}$ ) were not additive (Fig. $3 B$ ). This finding, together with inhibitory effects of nifedipine and cadmium, suggests that the increased ${ }^{45} \mathrm{Ca}$ uptake may be secondary to the Bk-induced depolarization.

\section{Effect of Bk on phosphoinositide metabolism}

\section{${ }^{3} \mathrm{H}$-Inositol phosphate formation}

The Bk receptor is linked to polyphosphoinositidase C (PIC) in several tissues (see Yano et al., 1984, 1985; Derian and Moskowitz, 1986; Jackson et al., 1987), including DRG neurons (Thayer et al., 1988). In agreement with their study, we found that 100 $\mathrm{nM}$ Bk caused a substantial increase in the radioactivity associated with various inositol polyphosphates, ${ }^{3} \mathrm{H}-\mathrm{Ins}(1,4,5) \mathrm{P}_{3}$, rising by a factor of 5 within $2 \sec$ (Fig 4).

The concentration-effect relationship for the increase in ${ }^{3} \mathrm{H}-$ $\mathrm{InsP}_{3}\left(\mathrm{EC}_{50}=6 \mathrm{nM}\right)$ is shown in Figure $5 .{ }^{3} \mathrm{H}$-InsP ${ }_{4}$ also rose; because of the rapidity of the responses, it was not possible to resolve a delay between the increase in ${ }^{3} \mathrm{H}-\mathrm{Ins}(1,4,5) \mathrm{P}_{3}$ and of ${ }^{3} \mathrm{H}$-Ins $\mathrm{P}_{4}$, which is formed by phosphorylation of $\operatorname{Ins}(1,4,5) \mathrm{P}_{3}$ (Irvine et al., 1986). Bk also increased the radioactivity associated with a fraction likely to be ${ }^{3} \mathrm{H}-\mathrm{Ins}(1,3,4) \mathrm{P}_{3}$ (see Materials
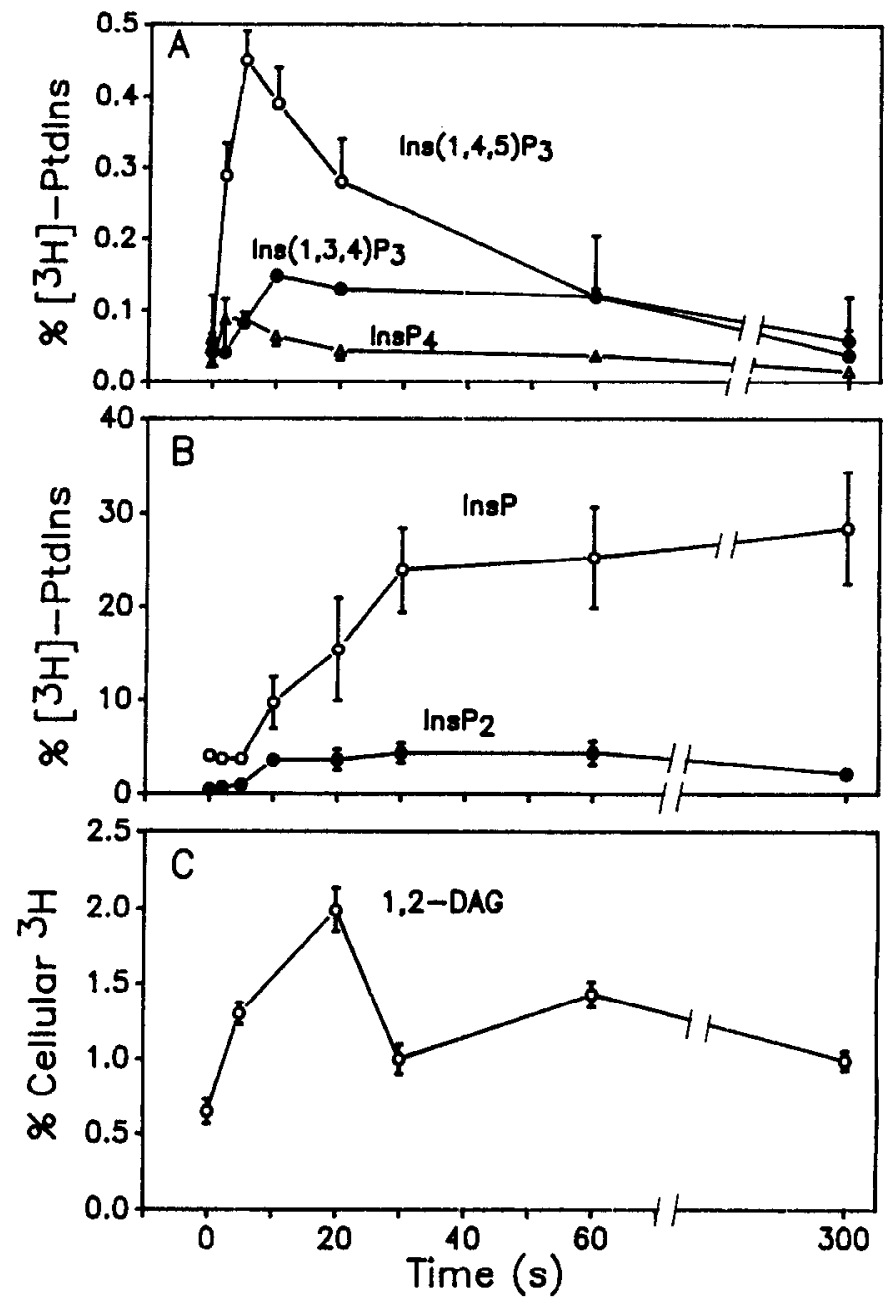

Figure 4. Time course of Bk-induced formation of ${ }^{3} \mathrm{H}$-inositol phosphates and ${ }^{14} \mathrm{C}-1,2, \mathrm{DAG}$ in DRG neurons. DRG neurons were incubated with $100 \mathrm{nM}$ Bk for the times indicated. In $A$, the inositol phosphates were separated by HPLC, and in $B$, by Dowex anion-exchange chromatography. For $A$ and $B$, the radioactivity in each fraction has been expressed as a percentage of the radioactivity in phosphatidylinositol $\left({ }^{3} \mathrm{H}\right]-$ PtdIns $)$, and the bars indicate SEM values for 5 experiments. For $C$, the radioactivity in the fraction corresponding to $1,2, \mathrm{DAG}$ was expressed as a percentage of the total radioactivity in each sample. Bars represent SEM values for 5 experiments. In some cases, the error bars lie within the symbols.

and Methods), but in this case, there was a delay of at least 2 $\mathrm{sec}$, reflecting the fact that production of $\operatorname{Ins}(1,3,4) \mathrm{P}_{3}$ occurs downstream of both $\operatorname{Ins}(1,4,5) \mathrm{P}_{3}$ and $\operatorname{Ins}(1,3,4,5) \mathrm{P}_{4}$ (Batty et al., 1985; Irvine et al., 1986). At most, the radioactivity in this fraction comprised about $24 \%$ of the total ${ }^{3} \mathrm{H}-\mathrm{InsP}_{3}$.

${ }^{3} \mathrm{H}$-inositol bisphosphate ( $\left(\mathrm{Ins}_{2}\right)$ and ${ }^{3} \mathrm{H}$-inositol phosphate (InsP) also rose, though more slowly, and remained elevated for at least 5 min during exposure of the cells to $100 \mathrm{~nm} \mathrm{Bk}$.

The cultures of DRG neurons contained only about $10 \%$ of non-neuronal cells; nevertheless, in order to confirm that the increase in inositol phosphates was occurring in the neurons, some experiments were done on ${ }^{3} \mathrm{H}$-inositol-labeled non-neuronal cell cultures derived from rat DRG. When these cells were exposed to Bk (up to $10 \mu \mathrm{M}$ ), no increase in ${ }^{3} \mathrm{H}$-inositol phosphates was detected $\left({ }^{3} \mathrm{H}-\mathrm{InsP}_{3}\right.$ was $104.2 \pm 4.2 \%$ of the basal value $20 \mathrm{sec}$ after treatment with $300 \mathrm{nM} \mathrm{Bk}$, triplicate determinations from 3 experiments). 
Figure 5. Concentration-effect curves for the Bk-induced formation of ${ }^{3} \mathrm{H}$ $\mathrm{InsP}_{3}$ and increase in the ${ }^{45} \mathrm{Ca}$ influx in DRG neurons. Protocols as in Figures 3 and 4 . For the InsP $_{3}$ curve, the increase is expressed as a percentage of the control for each experiment. The increase in the rate of ${ }^{45} \mathrm{Ca}$ uptake is expressed as a percentage of the maximum response for each individual experiment. Bars represent SEM values of between 4 and 5 experiments.

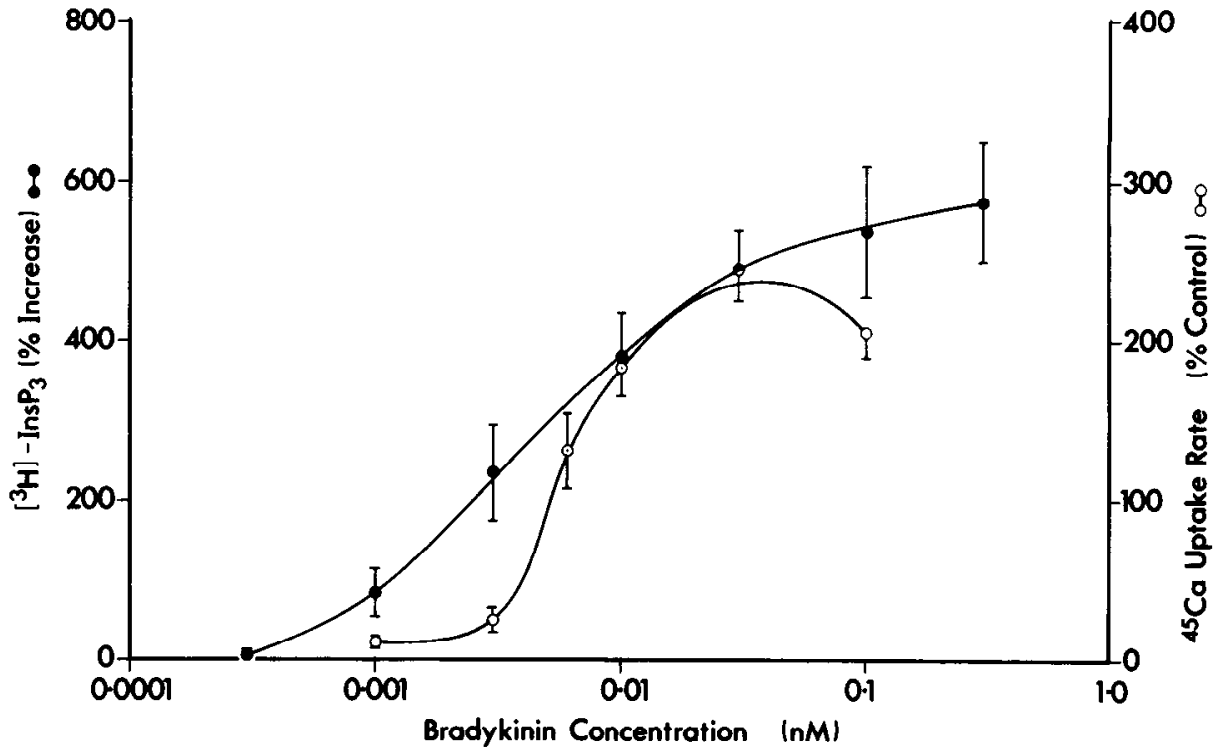

Exposure of DRG neurons to Bk results in desensitization of the electrophysiological response (see above). Desensitization of the ${ }^{3} \mathrm{H}$-InsP ${ }_{3}$ response was also observed. Exposure of DRG neurons for $60 \mathrm{sec}$ to either 30 or $100 \mathrm{nM} \mathrm{Bk}$ resulted in, respectively, a 50 or $80 \%$ inhibition of the response to a $20 \mathrm{sec}$ challenge with $100 \mathrm{~nm} \mathrm{Bk}$ (Table 2). To test the possibility that PKC might be involved in the desensitization, the effect of phorbol 12,13 dibutyrate (PDBu), which activates PKC directly, on the Bk-induced increase in $\left[{ }^{3} \mathrm{H}\right]-\mathrm{Ins} \mathrm{P}_{3}$ was measured. Table 2 shows that preincubation with $\mathrm{PDBu}(1 \mu \mathrm{M}$ for $60 \mathrm{sec})$ reduced the $\mathrm{Bk}$ response, whereas phorbol 12,13 didecanoate (PDDec, $10 \mu \mathrm{M}$ ), an $\alpha$-phorbol ester that does not activate PKC, had no effect.

\section{${ }^{14} \mathrm{C}$-1,2-Diacylglycerol formation}

Figure 4 also shows that concomitant with the elevation in ${ }^{3} \mathrm{H}$ inositol phosphates, $\mathrm{Bk}$ increased the radioactivity associated with 1,2,DAG in DRG neurons that had been labeled with ${ }^{14} \mathrm{C}$ arachidonic acid. ${ }^{14} \mathrm{C}-1,2, \mathrm{DAG}$ rose within $5 \mathrm{sec}$ of exposure to $100 \mathrm{~nm} \mathrm{Bk}$ (the earliest time at which a measurement was made), peaking between 5 and $20 \mathrm{sec}$. The radioactivity in 1,2,DAG then fell, rising for a second time between 30 and $60 \mathrm{sec}$ and was still 1.5-2 times the basal value at $5 \mathrm{~min}$. This secondary rise was also observed by Thayer et al. (1988).

Table 2. Desensitization of Bk-induced ${ }^{3} \mathrm{H}-\mathrm{InsP}_{3}$ formation

\begin{tabular}{lc} 
Treatment & $\begin{array}{c}\text { Response to } 100 \mathrm{nM} \text { Bk } \\
\text { (\% control response) }\end{array}$ \\
\hline None & 100 \\
Bk $30 \mathrm{nM}$ & $52.2 \pm 4.6$ \\
$\quad 100 \mathrm{nM}$ & $18 \pm 3.9$ \\
PDBu, $1 \mu \mathrm{M}$ & $56.3 \pm 6.4$ \\
PDDec, $10 \mu \mathrm{M}$ & $114 \pm 13$
\end{tabular}

DRG neurons equilibrated with ${ }^{3} \mathrm{H}$-inositol were pretreated with the solutions shown, washed, and then challenged $15 \mathrm{~min}$ later with $100 \mathrm{nM}$ Bk. Inositol phosphates were separated by Dowex anion-exchange chromatography. The test responses are expressed as a percentage of the response of cells pretreated with control solution. Mean and SEM values of 3-5 are shown.

\section{Effect of Bk on cellular ${ }^{14} \mathrm{C}$-arachidonic acid}

Application of $\mathrm{Bk}(100 \mathrm{nM})$ to DRG neurons also caused a small elevation in intracellular ${ }^{14} \mathrm{C}$-arachidonic acid, which rose to $140 \pm 10 \%(n=4)$ of the control value $30 \mathrm{sec}$ after administration of $\mathrm{Bk}$ and to $160 \pm 9 \%$ at $5 \mathrm{~min}$.

\section{Possible role of $\mathrm{Ca}^{2+}$ in the $\mathrm{Bk}$-induced activation of $\mathrm{PIC}$}

As PIC can be modulated by $\mathrm{Ca}^{2+}$ (Irvine et al., 1984a), it was possible that PIC activation and the resulting generation of second messengers was secondary to a Bk-mediated increase in $\left[\mathrm{Ca}^{2+}\right]_{i}$ rather than a direct consequence of receptor activation. This was tested by measuring the effect of $\mathrm{Ca}^{2+}$-free medium (buffered with $200 \mu \mathrm{M}$ EGTA) on the ability of Bk to increase Table 3. Possible role of $\mathrm{Ca}^{2+}$, eicosanoids, and DRG neuron
depolarization in the Bk-induced activation of PIC

\begin{tabular}{ll} 
Incubation conditions & ${ }^{3} \mathrm{H}-$ InsP $_{3}\left(\%\left[{ }^{3} \mathrm{H}\right]-P t d I n s\right)$ \\
\cline { 2 - 2 } & Control $\quad \mathrm{Bk}$ \\
\hline
\end{tabular}

A

$1.8 \mathrm{mM} \mathrm{CaCl}_{2}$ $\mathrm{Ca}^{2+}$-free medium

Nifedipine, $10 \mu \mathrm{M}$

Mepacrine, $20 \mu \mathrm{M}$

$\mathrm{BW} 755 \mathrm{C}, 20 \mu \mathrm{M}$

$\mathrm{K}^{+}, 50 \mathrm{~mm}$

Ionomycin $(1 \mu \mathrm{M})$

$\begin{array}{lr}0.20 \pm 0.03 & 0.94 \pm 0.2 \\ 0.11 \pm 0.035 & 0.64 \pm 0.17 \\ 0.21 \pm 0.028 & 0.87 \pm 0.21 \\ 0.19 \pm 0.024 & 1.2 \pm 0.11 \\ 0.23 \pm 0.05 & 1.12 \pm 0.08 \\ 0.37 \pm 0.068 & \\ 0.24 \pm 0.08 & \end{array}$

${ }^{14} \mathrm{C}-1,2, \mathrm{DAG}$ (\% total radioactivity)

B

$1.8 \mathrm{mM} \mathrm{CaCl}_{2}$

$\mathrm{Ca}^{2+}$-free medium

$$
0.70 \pm 0.3
$$

$2.2 \pm 0.17$

$0.53 \pm 0.28$

$1.7 \pm 0.35$

DRG neurons, equilibrated with ${ }^{3} \mathrm{H}$-inositol or ${ }^{14} \mathrm{C}$-arachidonic acid, were preincubated for $2 \mathrm{~min}$ in the test solutions; normal medium (1.8 $\mathrm{mm} \mathrm{CaCl}$ ); normal medium containing either $10 \mu \mathrm{M}$ nifedipine, $20 \mu \mathrm{M}$ mepacrine, or $20 \mu \mathrm{M}$ $\mathrm{BW} 755 \mathrm{C}$; $\mathrm{Ca}^{2+}$-free medium containing $200 \mu \mathrm{M}$ EGTA, and then transferred to an aliquot of the same medium with or without Bk ( $300 \mathrm{~nm}$ ) for $20 \mathrm{sec} .{ }^{3} \mathrm{H}-\mathrm{InsP} \mathrm{P}_{3}$ was measured as described in Table 2. Ionomycin and $\mathrm{K}^{+}$were applied for $20 \mathrm{sec}$ in normal medium. Mean and SEM values of between 3 and 5 experiments are given. 


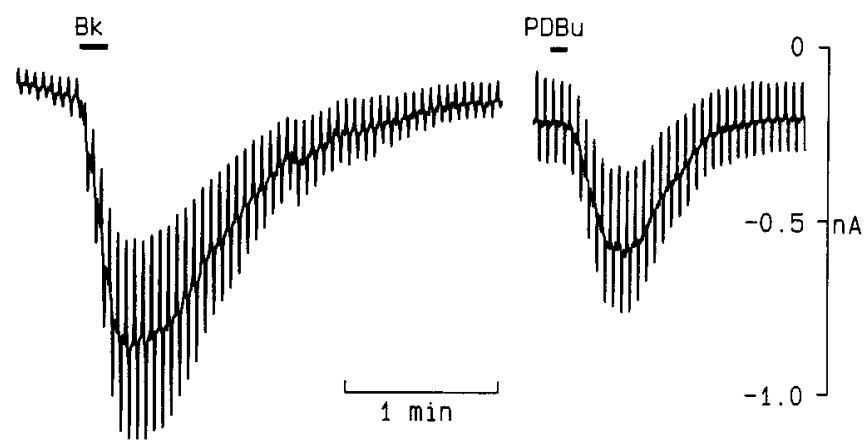

Figure 6. Membrane responses to Bk and PDBu in DRG neurons. Cells were monitored by whole-cell voltage-clamp recording. The holding potential was $-80 \mathrm{mV}$, with alternating $300 \mathrm{msec}$ steps to -60 and $-100 \mathrm{mV}$ giving rise to the upward and downward deflections on the current trace. Inward current is represented as a downward deflection. Both Bk $(1 \mu \mathrm{M}$ for $10 \mathrm{sec})$ and $\mathrm{PDBu}(1 \mu \mathrm{M}$ for $5 \mathrm{sec})$ elicited inward current responses associated with increased membrane conductance. The 2 records were obtained on different cells.

${ }^{3} \mathrm{H}-\mathrm{InsP}_{3}$ and ${ }^{14} \mathrm{C}-1,2$,DAG. Under these conditions the elevation of ${ }^{3} \mathrm{H}$-InsP ${ }_{3}$ (Table $3 \mathrm{~A}$ ) and the early rise in ${ }^{14} \mathrm{C}-1,2, \mathrm{DAG}$ (Table 3B) were not significantly different from the responses obtained in $1.8 \mathrm{mM} \mathrm{CaCl}_{2}$. Similarly, incubation of DRG neurons with nifedipine $(1 \mu \mathrm{M})$, which blocked the Bk-evoked increase in ${ }^{45} \mathrm{Ca}$ uptake (see Fig. 3), did not alter the ability of Bk to increase the level of ${ }^{3} \mathrm{H}$-InsP $\mathrm{P}_{3}$ (Table 3A).

Ionomycin $(1 \mu \mathrm{M}), \mathrm{a} \mathrm{Ca}^{2+}$-selective ionophore, which caused a substantial elevation of $\left[\mathrm{Ca}^{2+}\right]_{\mathrm{i}}$ in DRG neurons (not shown), and $50 \mathrm{mM} \mathrm{K}^{+}$, which (as seen in Fig. 3) increased the rate of ${ }^{45} \mathrm{Ca}$ entry, did not alter the basal level of ${ }^{3} \mathrm{H}$-InsP ${ }_{3}$ (Table 3A). These results show that activation of PIC was not secondary to an increase in $\left[\mathrm{Ca}^{2+}\right]_{i}$ or to depolarization.

Possible role of arachidonic acid and its metabolites in Bk-induced PIC activation

Metabolites of arachidonic acid, such as thromboxane A2, can act as positive-feedback regulators of phosphoinositide metabolism (Sha' affi and Naccache, 1985). In view of this, and because Bk increased intracellular ${ }^{14} \mathrm{C}$-arachidonic acid in DRG neurons, it was also necessary to determine whether PIC activation was secondary to increased eicosanoid production. Preincubation of DRG neurons with either mepacrine $(20 \mu \mathrm{M})$, an inhibitor of phospholipase A2 (PLA2), or BW755C ( $20 \mu \mathrm{M})$, a dual inhibitor of cyclooxygenase and lipoxygenase, had no effect on the Bkinduced increase in ${ }^{3} \mathrm{H}-\mathrm{InsP}_{3}$ (Table $3 \mathrm{~A}$ ).

\section{Pharmacology of the Bk-induced responses in DRG} neurons

The $\mathrm{EC}_{50}$ value for both the $\mathrm{Bk}$-induced increase in ${ }^{45} \mathrm{Ca}$ influx and in ${ }^{3} \mathrm{H}-\mathrm{Ins} \mathrm{P}_{3}$ formation was $6 \mathrm{nM}$ (Fig. 5). It has been suggested (Regoli et al., 1986) that there are two main Bk receptor subtypes, B1 and B2, which differ markedly in their sensitivity to des-Arginine ${ }^{9}$-bradykinin (des-Arg'-Bk) analogs. Des-Arg'-Bk $(1 \mu \mathrm{M})$, a putative B1 agonist, did not evoke an inward current response in cells that were subsequently shown to be responsive to $\mathrm{Bk}(1 \mu \mathrm{M})$, nor did it increase ${ }^{3} \mathrm{H}-\mathrm{InsP}_{3}$ formation or ${ }^{45} \mathrm{Ca}$ uptake at concentrations up to $30 \mu \mathrm{M}$ (triplicate determinations from 3 experiments in each case). Another Bk analog, D-Arginine-4-hydroxyproline ${ }^{2}-(\beta \text {-[2-thienyl]- } L \text {-alanine })^{5,8}$-D-phenylalanine ${ }^{7}$-bradykinin (D-Arg-Hyp ${ }^{2}-\mathrm{Thi}^{5,8}{ }^{5-\mathrm{D}-\mathrm{Phe}{ }^{7}-\mathrm{Bk} \text { ), reported as }}$ a potent Bk receptor antagonist (Beierwaltes et al., 1987; Stewart
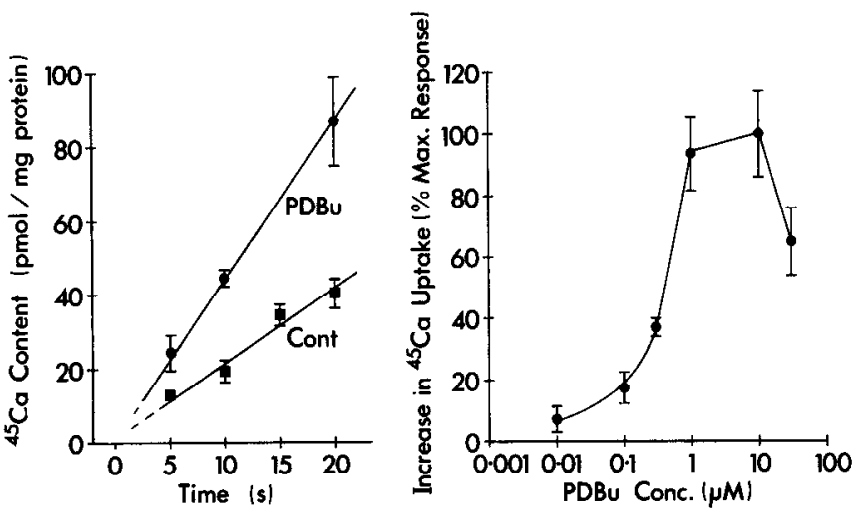

Figure 7. Effect of $\mathrm{PDBu}$ on the rate of ${ }^{45} \mathrm{Ca}$ uptake into $\mathrm{DRG}$ neurons. Left, Time course of ${ }^{45} \mathrm{Ca}$ uptake into DRG neurons in the presence and absence of PDBu $(1 \mu \mathrm{M})$ measured as described in Figure 2. Right, Concentration-effect curve. The increase in the rate of uptakc was cxpressed as a percentage of the maximum response for each experiment. The $\mathrm{EC}_{50}$. was about $300 \mathrm{nM}$. Bars represent SEM values for 3 experiments.

and Vavrek, 1987; Braas et al., 1988), inhibited the increase in ${ }^{3} \mathrm{H}$-InsP ${ }_{3}$ evoked by $5 \mathrm{nM}$ Bk with an $\mathrm{IC}_{30}$ value of $0.2 \pm 0.1$ $\mu \mathrm{M}$ (triplicate determinations from 4 experiments). It had a similar $\mathrm{IC}_{50}$ against Bk-induced ${ }^{45} \mathrm{Ca}$ uptake $(0.4 \mu \mathrm{M})$. At $10 \mu \mathrm{M}$ it inhibited the inward current induced by $0.3 \mu \mathrm{M} \mathrm{Bk}$ by $60 \%$ (data from 10 cells).

\section{Effect of pertussis toxin on Bk-induced responses in DRG neurons}

Pertussis toxin causes ADP-ribosylation of certain G-proteins $\left(G_{i}\right.$ and $\left.G_{o}\right)$ in neonatal rat DRG neurons (Scott and Dolphin, 1987), and in a few cell types it appears to inhibit the $G$ protein that links receptors to PIC (see Dolphin, 1987). Incubation of DRG neurons for $20 \mathrm{hr}$ with pertussis toxin $(200 \mathrm{ng} / \mathrm{ml}) \mathrm{had}$ no effect on the ability of $\mathrm{Bk}$ to increase ${ }^{3} \mathrm{H}$-inositol phosphates or to stimulate ${ }^{45} \mathrm{Ca}$ entry (Table 4). Additionally, in 3 electrophysiological experiments pertussis toxin treatment had no effect on either the proportion of cells responding to $\mathrm{Bk}(6 / 20$ cells in pertussis toxin-treated cultures, compared with $6 / 17$ in controls) or on the mean response amplitude.

Table 4. Effect of pertussis toxin on $\left[{ }^{3} \mathrm{H}\right]-\mathrm{InsP}_{3}$ formation and ${ }^{45} \mathrm{Ca}$ uptake in DRG neurons

\begin{tabular}{lll} 
& \multicolumn{3}{l}{${ }^{3} \mathrm{H}_{\text {Treatment }}\left(\%\left[{ }^{3} \mathrm{H}\right]-\mathrm{PtdIns}\right)$} \\
\cline { 2 - 3 } Control & \multicolumn{3}{l}{$\mathrm{Bk}$} \\
\hline Pertussis toxin $(200 \mathrm{ng} / \mathrm{ml})$ & $0.34 \pm 0.05$ & $1.2 \pm 0.16$ \\
& $0.40 \pm 0.07$ & $1.4 \pm 0.2$ \\
& ${ }^{45} \mathrm{Ca}$ uptake rate \\
& (pmol $/ \mathrm{min} / \mathrm{mg}$ protein $)$ \\
\hline
\end{tabular}

Control

$75.5 \pm 10 \quad 169 \pm 16$

Pertussis toxin $(200 \mathrm{ng} / \mathrm{ml})$

$69.0 \pm 12 \quad 177 \pm 21$

DRG neurons were incubated overnight with or without pertussis toxin (200 $\mathrm{ng} /$ $\mathrm{ml}) .{ }^{3} \mathrm{H}-\mathrm{InsP} \mathrm{P}_{3}$ formation and ${ }^{45} \mathrm{Ca}$ uptake induced by $300 \mathrm{~nm} \mathrm{Bk}$ for $20 \mathrm{sec}$ were measured as described in Table 2 and Figure 2. Mean and SEM values of 4 experiments are given. 
Table 5. Effect of phorbol esters and OAG on the rate of ${ }^{45} \mathrm{Ca}$ uptake in DRG neurons

\begin{tabular}{lcl} 
& $\begin{array}{l}{ }^{45} \mathrm{Ca} \text { uptake rate } \\
\text { (pmol/min/mg } \\
\text { protein) }\end{array}$ \\
\hline Treatment & $70.2 \pm 5.0$ & \\
Control & $171.0 \pm 21.8$ & \\
Bk, 300 nM & $183.7 \pm 26.3$ & \\
PDBu $(1 \mu \mathrm{M})$ & $155.0 \pm 16.5$ & \\
PMA $(1 \mu \mathrm{M})$ & $75.4 \pm 7.7$ & \\
PDDec $(10 \mu \mathrm{M})$ & $157.9 \pm 30$ & \\
OAG $(1 \mu \mathrm{M})$ & $273.4 \pm 22.4$ & \\
$\mathrm{~K}^{+}, 50 \mathrm{mM}$ & $160.3 \pm 18.8$ & \\
PDBu $(1 \mu \mathrm{M})+\mathrm{Bk}(300 \mathrm{nM})$ & $167.5 \pm 16.7$ & \\
OAG $(1 \mu \mathrm{M})+\mathrm{Bk}(300 \mathrm{nM})$ & $259.0 \pm 27.8$ & \\
PDBu $(1 \mu \mathrm{M})+\mathrm{K}+(50 \mathrm{mM})$ & & Nifedipine \\
& Normal & $(1 \mu \mathrm{M})$ \\
\hline Control & $87.6 \pm 6$ & $73.0 \pm 4.7$ \\
PDBu $(1 \mu \mathrm{M})$ & $159.6 \pm 18$ & $78.8 \pm 8.2$ \\
\end{tabular}

The rate of ${ }^{45} \mathrm{Ca}$ entry was measured as described for Figure 2. DRG neurons were incubated with either control or drug-containing solutions (Bk, PDBu, PMA, PDDec, OAG, high $\mathrm{K}^{+}$, or a combination of these) for $30 \mathrm{sec}$ and then transferred to the same solution but containing ${ }^{45} \mathrm{Ca}$ for $20 \mathrm{sec}$. Nifedipine was applied $2 \mathrm{~min}$ prior to and during the application of the agonists. Mean and SEM values of between 3 and 4 experiments are shown.

Possible role of PKC in the responses of DRG neurons to BK

\section{Effects of phorbol esters}

Since Bk was found to increase the formation of ${ }^{14} \mathrm{C}-1,2, \mathrm{DAG}$, an endogenous activator of PKC, in DRG neurons (see Fig. 4), the possibility that this pathway could be involved in the excitatory effects of $\mathrm{Bk}$ was tested by comparing the effects of PKC-activation by phorbol esters with those of Bk.

Electrophysiological responses to phorbol esters. As shown in Figure 6, PDBu (1 $\mu \mathrm{M}$ applied for $5 \mathrm{sec}$ ) gave a response that was very similar to that produced by $\mathrm{Bk}$, consisting of an inward current (mean amplitude, $0.36 \pm 0.07 \mathrm{nA}$ at $-80 \mathrm{mV} ; n=90$ ) associated with increased membrane conductance. The response to $\mathrm{PDBu}$ was generally delayed in onset compared with the $\mathrm{Bk}$ response, reaching a peak at $29 \pm 2 \sec (n=90)$ and was somewhat longer-lasting (2-5 min). As with $\mathrm{Bk}, \mathrm{PDBu}$ occasionally caused a much slower inward current response (also associated with an increase in membrane conductance), lasting for up to $15 \mathrm{~min}$, or evoked unclamped neurite action potentials with no response at the soma membrane; these have not been included in the analysis. A second application of PDBu produced no effect, or sometimes a greatly reduced response. PDDec (10 $\mu \mathrm{M})$ did not produce a membrane response.

The proportion of cells that responded to $\mathrm{PDBu}$ with an inward current was $37 \%(90 / 241)$, similar to the proportion responding to $\mathrm{Bk}$. If PKC activation is involved in the mechanism whereby Bk causes an inward current, then PDBu-insensitive cells, which presumably lack the relevant PKC or PKC-activated ion channel, would not be expected to respond to $\mathrm{Bk}$. In fact, a small proportion of the PDBu-insensitive cells $(19 \%, 22 / 112)$ gave an inward current response to $\mathrm{Bk}$, which argues against $\mathrm{PKC}$ being the only mechanism involved in excitation by $\mathrm{Bk}$.

In most cells, the inward current response to $\mathrm{PDBu}$ was abolished in low $(8.3 \mathrm{~mm})$ sodium medium. Thus, in 3 experiments in which the solution was switched between normal and low sodium $(8.3 \mathrm{~mm}$ ) Locke, $10 / 19$ cells responded to $\mathrm{PDBu}$ in normal Locke solution (mean current amplitude, $0.32 \pm 0.07$ nA) compared with $2 / 14$ responding to $\mathrm{PDBu}$ in low- $\mathrm{Na}^{+}$solution (current amplitudes, $<0.05 \mathrm{nA}$ ). In contrast, the very slow inward current response to $\mathrm{PDBu}$ is unaffected by removal of $\mathrm{Na}^{+}$(Lindsay and Rang, 1988). The PDBu response also resembled the fast $\mathrm{Bk}$ response in that it could be obtained in $\mathrm{Ca}^{2+}$-free Locke solution. In $\mathrm{Ca}^{2+}$-free Locke $13 / 32$ cells responded to $\mathrm{PDBu}(40.6 \%)$ compared with $37 \%$ (see above) in normal Locke.

${ }^{45}$ Ca uptake induced by phorbol esters. PDBu $(1 \mu \mathrm{M})$ increased the rate of entry of ${ }^{45} \mathrm{Ca}$ into DRG neurons (Fig. 7). Maximal concentrations of Bk and PDBu produced approximately similar increases in ${ }^{45} \mathrm{Ca}$ influx. Phorbol myristate acetate (PMA), another active phorbol ester, also stimulated ${ }^{45} \mathrm{Ca}$ uptake, as did the synthetic diacylglycerol, oleoyl-acetyl-glycerol (OAG, $1 \mu \mathrm{M}$ ), whereas PDDec had no effect (Table 5). The responses to maximal concentrations of BK and PDBu were not additive, implying that a similar mechanism could be operating for both agonists (Table 5). Additionally, the response to PDBu $(1 \mu \mathrm{M})$, like that of $\mathrm{Bk}$, was not additive with the response to a maximally effective concentration ( $50 \mathrm{mM}$ ) of $\mathrm{K}^{+}$, and could be blocked by nifedipine (Table 5).

\section{Effect of down-regulation and inhibition of PKC on Bk-induced responses}

If PKC mediates some of the actions of Bk in DRG neurons, then preventing its activation should interfere with these responses. PKC activation can be prevented in 2 ways: (1) by prolonged incubation of cclls with phorbol esters, which leads to down-regulation of PKC (Young et al., 1987), and (b) by the use of inhibitors such as staurosporine (Tamaoki et al., 1986).

\section{Effect of $P K C$ down-regulation on responses to $B k$ and $P D B u$}

Incubation of DRG neurons for $18 \mathrm{hr}$ with $300 \mathrm{~nm} P D B u$, a protocol that causes loss of PKC from rat glioma cells (Young et al., 1987), resulted in marked loss of PKC-associated immunoreactivity as measured with an antibody (MC5) that recognizes the $\alpha$ - and $\beta$-forms of PKC (see also Ewald et al., 1988a). This treatment prevented the increase in ${ }^{45} \mathrm{Ca}$ uptake induced by both $\mathrm{Bk}$ and $\mathrm{PDBu}$ (Table 6 ) and greatly reduced the number of cells that showed electrophysiological responses to both agents. Thus, in 5 experiments, in which control cultures from the same batch of cells were compared with cultures incubated overnight with $\mathrm{PDBu}$, the proportion of Bk-responsive cells was reduced from 42 to $13 \%$ and the proportion of PDBu-responsive cells was reduced from 62 to $7 \%$ (see Table 6 ). Table 6 also shows that the down-regulation protocol did not affect the ability of $\mathrm{Bk}$ to activate PIC, as the Bk-induced increase in ${ }^{3} \mathrm{H}-\mathrm{InsP}_{3}$ formation remained unchanged after overnight treatment with PDBu.

\section{Effect of staurosporine on the responses to $B k$ and $P D B u$}

Staurosporine inhibited the increase in ${ }^{45} \mathrm{Ca}$ uptake induced by $\mathrm{Bk}$ and $\mathrm{PDBu}$ (Fig. 8). The $\mathrm{IC}_{30}$ value for inhibition of $\mathrm{Bk}$ induced ${ }^{45} \mathrm{Ca}$ uptake was about $20 \mathrm{~nm}$; it had no effect on the increased ${ }^{45} \mathrm{Ca}$ uptake induced by $50 \mathrm{~mm} \mathrm{~K} \mathrm{~K}^{+}$. Staurosporine also abolished the electrophysiological response to $\mathrm{PDBu}$, reducing the percentage of responsive cells from $55 \%(16 / 29)$ to $0 \%(0 /$ 19). The effect of staurosporine on the electrophysiological response to $\mathrm{Bk}$ was less clear cut, the percentage of responsive 
cells being reduced from $47.5 \%(19 / 40)$ to $30 \%(8 / 26)$. The amplitudes of the inward currents in those cells that responded were not significantly different from the controls. The reason for the discrepancy between the effect of PKC down-regulation and inhibition of PKC with staurosporine on the proportion of cells that responded to Bk with an inward current is not clear.

\section{Discussion}

The aim of the experiments reported here was to examine the role of second messengers in excitation of sensory neurons by $\mathrm{Bk}$. The approach taken was to determine whether exposure of DRG neurons to $\mathrm{Bk}$ resulted in the formation of any intracellular messengers and then to determine if there was any correlation between these changes and the ability of $\mathrm{Bk}$ to cause an inward, depolarizing current and to increase $\mathrm{Ca}^{21}$ influx, responses likely to be important for, respectively, neuronal excitation and neurotransmitter release.

\section{Bradykinin activates PIC in sensory neurons}

The results of these experiments provide clear evidence that $\mathrm{Bk}$ activates PIC in sensory neurons from rat DRG, producing a rapid increase in $\operatorname{Ins}(1,4,5) \mathrm{P}_{3}$ and 1,2,DAG. BK does not activate PIC in non-neuronal cells from rat DRG, though it does cause an increase in cAMP in these cells (Burgess et al., in press). The biphasic nature of the 1,2,DAG response in the neurons may mean that some 1,2,DAG is formed by another mechanism, for example, the hydrolysis of either phosphatidylinositol (see Imai and Gershengorn, 1986; Griendling et al., 1987) or phosphatidylcholine (see Besterman et al., 1986; Irving and Exton, 1987). In 2 experiments we found that removal of extracellular $\mathrm{Ca}^{2+}$ prevented the secondary increase in 1,2,DAG, leaving the initial rise unaltered, and this supports the hypothesis that 2 mechanisms are involved.

Bk also increased the cellular level of ${ }^{14} \mathrm{C}$-arachidonic acid. Whether this occurred as a consequence of PIC activation or whether, as has been described in fibroblasts (Burch and Axelrod, 1987), the Bk receptor is linked directly to PLA2 in DRG neurons has not been examined.

\section{Is PIC activation related to sensory neuron excitation by} $\mathrm{Bk}$ ?

Both inositol phosphates and 1,2,DAG have important secondmessenger functions in many tissues (see Berridge, 1987), and arachidonic acid products can also act as intracellular messengers, regulating the activity of plasma membrane ion channels

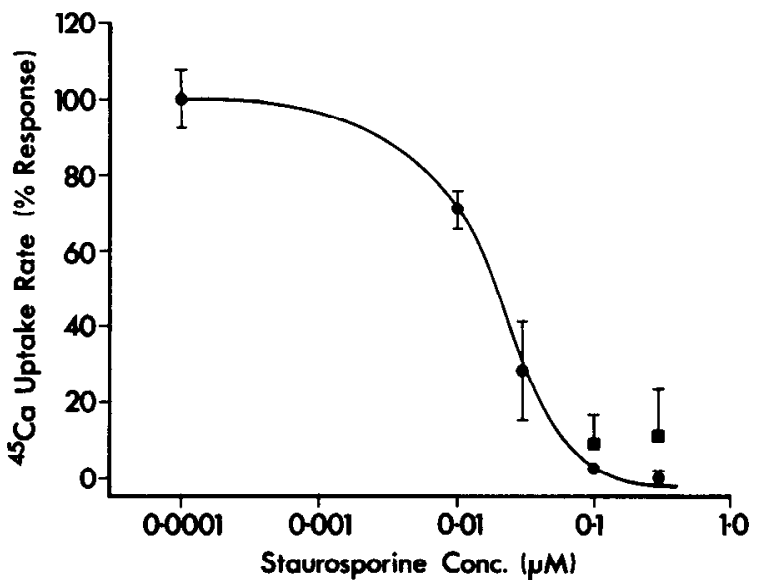

Figure 8. Effect of staurosporine on the Bk- and PDBu-induced increase in the rate of uptake of ${ }^{45} \mathrm{Ca}$ into DRG neurons. DRG neurons were preincubated for $2 \mathrm{~min}$ with the $\mathrm{PKC}$ inhibitor staurosporine at the concentrations indicated. The neurons were then exposed to solutions containing $100 \mathrm{nM} \mathrm{Bk}(\theta)$ or $1 \mu \mathrm{M}$ PDBu (D) and the indicated concentrations of staurosporine, and the increase in the rate of ${ }^{45} \mathrm{Ca}$ uptake was measured as described for Figure 3 . The increase in the rate of ${ }^{45} \mathrm{Ca}$ uptake was expressed as a percentage of the response to $100 \mathrm{nM}$ $\mathrm{Bk}$ in the absence of staurosporine. Bars represent SEM values for 3 experiments.

(Piomelli et al., 1987). These molecules could therefore be considered as mediators of the Bk-induced excitation or increase in ${ }^{45} \mathrm{Ca}$ influx, provided certain criteria are fulfilled. In particular, the time course of the biochemical response must be fast enough to account for the electrophysiological events, and the pharmacology should correspond. The possibility that the biochemical response could be occurring as a consequence of the membrane responses must also be considered. These questions have been examined using ${ }^{3} \mathrm{H}$-Ins $\mathrm{P}_{3}$ formation as an index of PIC activation. No detailed examination of arachidonic acid products as possible mediators of the membrane events has been made, beyond showing that an increase in arachidonic acid and its metabolites is not required for Bk-induced activation of PIC.

\section{Pharmacology of Bk responses}

Both the biochemical and electrophysiological responses of DRG neurons appeared to be mediated by the subtype of $\mathrm{Bk}$ receptor classified by Regoli et al. (1986) as B2. The responses could not be elicited by des-Arg'-Bk (reported to be selective for $\mathrm{B} 1$ re-

\begin{tabular}{|c|c|c|c|}
\hline Assay & Treatment & Control & $\begin{array}{l}\text { PKC down- } \\
\text { regulated }\end{array}$ \\
\hline${ }^{45} \mathrm{Ca}$ uptake rate $(\mathrm{pmol} / \mathrm{min} / \mathrm{mg}$ protein) & $\begin{array}{l}\text { None } \\
\mathrm{Bk}, 300 \mathrm{nM} \\
\mathrm{PDBu}, 1 \mu \mathrm{M}\end{array}$ & $\begin{aligned} 79.5 & \pm 8.6 \\
125.3 & \pm 7.7 \\
171.9 & \pm 30.0\end{aligned}$ & $\begin{array}{l}64.5 \pm 11.5 \\
73.9 \pm 6.9 \\
74.5 \pm 16.6\end{array}$ \\
\hline $\begin{array}{l}\text { Inward current } \\
\text { (cells responding/cells tested) }\end{array}$ & $\begin{array}{l}\mathrm{Bk}, 1 \mu \mathrm{M} \\
\mathrm{PDBu}, 1 \mu \mathrm{M}\end{array}$ & $\begin{array}{l}19 / 45 \\
22 / 35\end{array}$ & $\begin{array}{l}6 / 47 \\
3 / 42\end{array}$ \\
\hline${ }^{3} \mathrm{H}$-Ins $\mathrm{P}_{3}$ formation ( $\%$ basal value) & $\mathrm{Bk}, 100 \mathrm{nM}$ & $408 \pm 55$ & $531 \pm 64$ \\
\hline
\end{tabular}

DRG neurons were incubated for $18 \mathrm{hr}$ in the presence or absence of $300 \mathrm{nM} \mathrm{PDBu}$, then washed and allowed to recover for $90 \mathrm{~min}$. The rate of ${ }^{45} \mathrm{Ca}$ uptake was measured as described in Figure 3 , the formation of ${ }^{3} \mathrm{H}$-InsP $\mathrm{P}_{3}$ was measured as described in Table 2, and the inward current response was measured as described for Figures 1 and 6 . Mean \pm SEM values for 3 experiments are given. 
ceptors), and they were inhibited by the $\mathrm{Bk}$ receptor antagonist $\mathrm{D}-$ Arg-Hyp ${ }^{2}-\mathrm{Thi}^{5,8}-\mathrm{D}-\mathrm{Phe}^{7}-\mathrm{Bk}$. Nociceptor excitation by $\mathrm{Bk}$ is also believed to involve B2 receptors (Whalley et al., 1987; Steranka et al., 1988).

None of the Bk-mediated responses tested were blocked by pretreatment of the cells with pertussis toxin, implying that the Bk receptor involved was not linked to either $G_{i}$ or $G_{0}$. Although the pertussis toxin sensitivity of the $1,2, \mathrm{DAG}$ response was not examined, the fact that Bk-induced formation of Ins $\mathrm{P}_{3}$ was not affected by pertussis toxin means that Bk does increase $1,2, D A G$ in pertussis toxin-treated cells. Pertussis toxin has been shown to block the actions of a variety of neurotransmitters and peptides that inhibit $\mathrm{Ca}^{2+}$ currents in DRG neurons (see Holz et al., 1986; Ewald et al., 1988b), implying that a $G_{i}$ or $G_{0}$-like protein may couple inhibitory receptors to $\mathrm{Ca}^{2+}$ channels in sensory neurons. It seems that the Bk receptor, which mediates excitation of DRG neurons, is coupled to PIC, and possibly to other effectors, by a pertussis toxin-insensitive G-protein.

\section{Time course of the responses}

The formation of $\operatorname{Ins}(1,4,5) \mathrm{P}_{3}$ and $1,2, \mathrm{DAG}$ both occur rapidly in response to $\mathrm{Bk},{ }^{3} \mathrm{H}$-Ins $(1,4,5) \mathrm{P}_{3}$ (and ${ }^{3} \mathrm{H}$-Ins $\mathrm{P}_{4}$ ) reaching a peak in 2-5 sec, and ${ }^{14} \mathrm{C}-1,2, \mathrm{DAG}$ in about $20 \mathrm{sec}$. This is rapid enough to account for both the increase in ${ }^{45} \mathrm{Ca}$ uptake and the inward current.

\section{Could PIC activation be secondary to the membrane response?}

Manipulations designed to mimic or prevent the $\mathrm{Bk}$-induced increase in $\mathrm{Ca}^{2+}$ entry, to prevent the formation and metabolism of arachidonic acid or to mimic the $\mathrm{Bk}$-induced depolarization had no cffect on ${ }^{3} \mathrm{H}-\mathrm{InsP}_{3}$ formation. This suggests that activation of $\mathrm{PIC}$ was a direct consequence of $\mathrm{Bk}$ receptor activation and not secondary to other Bk-induced changes in the DRG neurons.

\section{Involvement of PKC}

The evidence discussed so far is consistent with the hypothesis that PIC activation is responsible for the excitatory effects of Bk on sensory neurons but does not exclude other possibilities, for example, that $\mathrm{Bk}$ receptors are coupled to an ion channel either directly or via a G-protein.

There is much evidence that the main role of the inositol phosphates, particularly $\operatorname{Ins}(1,4,5) \mathrm{P}_{3}$, is to raise $\left[\mathrm{Ca}^{2+}\right]_{\mathrm{i}}$ (see Berridge, 1987), and in sensory neurons, as in many other cell types, this has the effect of opening $\mathrm{K}^{+}$and $\mathrm{Cl}^{-}$channels (Gorke and Pierau, 1980; Kameyama, 1983; Mayer, 1985), which exerts an inhibitory rather than an excitatory effect. 1,2,DAG, which is an endogenous activator of PKC (see Nishizuka, 1988) appeared, therefore, to be a stronger candidate for a second messenger than the inositol phosphates. Not only is PKC particularly abundant in neuronal tissue (Girard et al., 1986; Worley et al., 1986), but it has been implicated as a key regulator of neuronal function (see Kaczmarek, 1987; Miller, 1987); furthermore, it has recently been implicated as a mechanism in C-fiber depolarization (Bettaney et al., 1988; Dray et al., 1988; Rang and Ritchie, 1988). The depolarizing phase of the complex response of NG108-15 cells to Bk has also been linked to PKC activation (Brown and Higashida, 1988). It seemed possible, therefore, that PKC might also be the link between the Bk receptor and DRG neuron excitation.

In support of this, it was found that PDBu caused membrane responses that closely resembled those produced by Bk. The most common type of response elicited by both $\mathrm{Bk}$ and $\mathrm{PDBu}$ was an inward current associated with an increase in membrane conductance. For both agents, this inward current response could be evoked in the absence of $\mathrm{Ca}^{2+}$ but was blocked in the absence of $\mathrm{Na}^{+}$. This suggests that $\mathrm{Na}^{+}$is the main charge carrier, but on the basis of its insensitivity to TTX and relative lack of voltage dependence, the channel involved does not correspond to the fast voltage-gated $\mathrm{Na}^{+}$channel. The ionic selectivity and gating characteristics of this channel need more detailed study to establish whether Bk and PDBu activate the same ion channel. Bk and PDBu sometimes produced very slow inward current responses, and preliminary results suggested that the slow response to $\mathrm{PDBu}$ was due to activation of chloride conductance (see Lindsay and Rang, 1988). It is unclear why the pattern of response shows this variation, but the fact that very similar results were obtained with $\mathrm{Bk}$ and $\mathrm{PDBu}$ supports the hypothesis that PKC may be involved in the electrophysiological effects of Bk. A direct effect of PKC activation in causing the opening of ion channels, as distinct from a modulatory effect on voltageor $\mathrm{Ca}^{2+}$-activated channels, has not hitherto been described, except in C-fiber axons (Rang and Ritchie, 1987, 1988) and may be a mechanism unique to nociceptive neurons.

It had previously been shown (Perney et al., 1986) that substance $P$ release from DRG neurons could be blocked by dihydropyridine $\mathrm{Ca}^{2+}$ antagonists. It seemed likely, therefore, that activators of DRG neurons would stimulate $\mathrm{Ca}^{2+}$ entry, but this had not been demonstrated experimentally. Here, it has been shown that $\mathrm{Bk}$ increases ${ }^{45} \mathrm{Ca}$ uptake into $\mathrm{DRG}$ neurons by a nifedipine-sensitive mechanism and that this effect could be mimicked by PKC activators such as PDBu, PMA, and OAG. Neither Bk nor PDBu caused a further increase in $\mathrm{Ca}^{2+}$ uptake in $\mathrm{K}^{+}$-depolarized neurons, suggesting that neither acts directly on $\mathrm{Ca}^{2+}$ permeability.

\section{Effects of inhibition and down-regulation of $P K C$}

The strongest evidence implicating PKC in the excitation of DRG neurons by Bk comes from experiments in which PKC activation was prevented. Thus, down-regulation of PKC by prolonged exposure to PDBu, which led to marked loss of PKCassociated immunoreactivity (see also Young et al., 1987; Ewald et al., 1988a), completely blocked the ability of Bk and PDBu to stimulate $\mathrm{Ca}^{2+}$ influx, and the proportion of cells responding to $\mathrm{Bk}$ with an inward current was much reduced. The ability of Bk to increase ${ }^{3} \mathrm{H}-\mathrm{InsP}_{3}$ formation was, however, unaltered, implying that PIC activation was not secondary to activation of $\mathrm{PKC}$ and that the treatment had not compromised the BK receptor or any part of the signal-transduction pathway through to the generation of inositol phosphates. Additionally, the ability of both $\mathrm{PDBu}$ and $\mathrm{Bk}$, but not $\mathrm{K}^{+}$, to stimulate $\mathrm{Ca}^{2+}$ influx was blocked by staurosporine, a potent inhibitor of $\mathrm{PKC}$ in vitro (Tamaoki et al., 1986). Staurosporine is not specific for PKC, but inhibits a wide variety of protein kinases, including CAMPand cGMP-dependent protein kinases (see Tamaoki et al., 1986). Bk does not, however, increase cAMP in DRG neurons, and although it does increase cGMP, this is unlikely to be responsible for the ${ }^{45} \mathrm{Ca}$ uptake, as neither dibutyryl-cGMP or sodium nitroprusside (which activates guanylate cyclase directly) alters the rate of ${ }^{45} \mathrm{Ca}$ uptake (Burgess et al., in press). The lack of effect of staurosporine on the $\mathrm{K}^{+}$-induced ${ }^{45} \mathrm{Ca}$ uptake suggests that it was not blocking $\mathrm{Ca}^{2+}$ channels directly, so it is likely that its action on Bk- and PDBu-mediated $\mathrm{Ca}^{2+}$ influx is at the level of PKC, although effects on other kinases cannot be ruled out. 
The effect of staurosporine on the electrophysiological responses to Bk in DRG neurons was not so clear cut. Staurosporine reduced the proportion of cells that responded to $\mathrm{Bk}$, but was less effective in this regard than down-regulation of PKC; the reason for this discrepancy is not known. The observations that some cells were able to respond to $\mathrm{Bk}$, both in the presence of staurosporine and when PKC had been down-regulated and that a small number of PDBu-insensitive cells responded to $\mathrm{Bk}$, combine to suggest that $\mathrm{PKC}$ activation is not the only mechanism by which DRG neurons can be activated by $\mathrm{Bk}$. On the other hand, excitation of C-fibers in the tail of the neonatal rat by both $\mathrm{Bk}$ and PDBu is strongly blocked by staurosporine (Bettaney et al., 1988; Dray et al., 1988), suggesting that $\mathrm{PKC}$ activation may be important in vivo.

\section{How does $P K C$ activation control $\mathrm{Ca}^{2+}$ entry?}

The increase in $\mathrm{Ca}^{2+}$ uptake induced by either $\mathrm{Bk}$ or PDBu was not additive with that induced by $\mathrm{K}^{+}$, and the effect of all 3 agents was blocked by nifedipine. This suggests that $\mathrm{Bk}$ and PDBu both act by causing depolarization rather than by opening $\mathrm{Ca}^{2+}$ channels directly.

There is evidence from several tissues that PKC can regulate the activity of voltage-activated $\mathrm{Ca}^{2+}$ channels. In Aplysia neurons (DeRiemer et al., 1985) and NG108-15 cells (Osugi et al., 1986), PKC activation facilitates $\mathrm{Ca}^{2+}$ currents, and in $\mathrm{A}_{7} \mathrm{r}_{5}$ smooth muscle cells phorbol esters cause an increase in the rate of dihydropyridine-sensitive $\mathrm{Ca}^{2+}$ influx (Sperti and Colucci, 1987). On the other hand, PKC activation attenuates $\mathrm{Ca}^{2+}$ currents in PC1 2 cells (Di Virgilio et al., 1986), aortic muscle cells (Galizzi et al., 1987), and, notably, chick DRG neurons (Rane and Dunlap, 1986). Inhibition of $\mathrm{Ca}^{2+}$ currents by neuropeptide $Y$ in rat DRG neurons has also been attributed to PKC activation (Ewald et al., 1988a). Neither Bk nor PDBu affected the increase in $\mathrm{Ca}^{2+}$ uptake in response to $\mathrm{K}^{+}$, which argues against a strong facilitatory or inhibitory effect of PKC on the nifedipine-sensitive $\mathrm{Ca}^{2+}$ channels of these cells. The studies of Rane and Dunlap (1986) and Ewald et al. (1988a) suggest that PKC activation inhibits L-type $\mathrm{Ca}^{2+}$ currents, and we plan to test whether Bk has a similar effect in rat DRG neurons.

\section{Comparison with NG108-15 cells}

The NG108-15 cell line, which possesses PIC-linked Bk receptors (Yano et al., 1984, 1985; Higashida et al., 1986; Brown and Higashida, 1988), has been used as a model to characterize the roles of the second messengers of the phosphoinositide system in the response of neuronal cells to Bk. Though there are superficial similarities between DRG neurones and NG108-15 cells, in that both show a depolarization and an increase in dihydropyridine-sensitive $\mathrm{Ca}^{2+}$ uptake in response to $\mathrm{Bk}$ and to phorbol esters, the mechanism for the depolarizing response seems to be dissimilar. Thus, in NG108-15 cells the PKC-mediated depolarization is accompanied by a decrease, rather than an increase in membrane conductance, which is associated with inhibition of a voltage-sensitive $\mathrm{K}^{+}$current (see Brown and Higashida, 1988).

Another difference between the cells is that NG108-15 cells respond to $\mathrm{Bk}$ with an initial hyperpolarization, associated with an Ins $(1,4,5) \mathrm{P}_{3}$-mediated increase in $\left[\mathrm{Ca}^{2+}\right]_{\text {, }}$, and the opening of $\mathrm{Ca}^{2+}$-activated $\mathrm{K}^{+}$channels (Brown and Higashida, 1988). This hyperpolarizing response is not seen in DRG neurons, despite a substantial increase in $\operatorname{Ins}(1,4,5) \mathrm{P}_{3}$. This lack of a $\mathrm{Ca}^{21}$-mediated hyperpolarization in $\mathrm{DRG}$ neurons is surprising since these cells are known to possess $\mathrm{Ca}^{2+}$-gated $\mathrm{K}^{+}$channels (Gorke and Pierau, 1980; Kameyama, 1983). Although Thayer et al. (1988) have recently reported that $100 \mathrm{nM} \mathrm{Bk}$ increases $\left[\mathrm{Ca}^{2+}\right]_{\mathrm{i}}$ in the soma of DRG neurons, the peak $\left[\mathrm{Ca}^{2+}\right]_{i}$ observed was only about $200 \mathrm{nM}$, which may be insufficient to activate $\mathrm{Ca}^{2+}$ gated $\mathrm{K}^{+}$channels.

\section{Effect of PKC activation on Bk-induced formation of Ins $P_{3}$}

An important role of the DAG/PKC pathway in many tissues is down-regulation of receptor-activated changes in phosphoinositide metabolism and $\mathrm{Ca}^{2+}$ signaling (e.g., Leeb-Lundberg et al., 1985; Vincentini et al., 1985; Watson and Lapetina, 1985; Liles et al., 1986; Francel et al., 1987; Osugi et al., 1987). Desensitization of the membrane response to $\mathrm{Bk}$ and the increase in ${ }^{3} \mathrm{H}$-InsP ${ }_{3}$ was very marked in DRG neurons. Pretreatment of the cells with PDBu transiently reduced the Bk-evoked increase in ${ }^{3} \mathrm{H}$-InsP $\mathrm{P}_{3}$. This suggests that prior exposure to $\mathrm{Bk}$ or $\mathrm{PDBu}$ modulates either the receptor, PIC, or the G-protein that links them. The site(s) at which PKC exerts its effect and its possible involvement in desensitization are under investigation.

\section{Conclusions}

Our results suggest the following sequence of events when Bk is applied to DRG neurons. First, PIC is activated, leading to an increase in the cellular level of $\operatorname{Ins}(1,4,5) \mathrm{P}_{3}$ and 1,2,DAG. The increase in 1,2,DAG activates PKC, which in turn causes an inward current by opening $\mathrm{Na}^{+}$channels and hence depolarizes the neurons. It is likely, however, that other mechanisms, such as channels linked directly to the Bk receptor via a G-protein or operated by arachidonic acid or an inositol phosphate, contribute to the depolarizing effect of $\mathrm{Bk}$ in a proportion of cells. The depolarization, by opening voltage-regulated $\mathrm{Ca}^{2+}$ channels, is responsible for the Bk-induced increase in $\mathrm{Ca}^{2+}$ influx.

These results provide more evidence for the suggestion (see Bettaney et al., 1988; Dray et al., 1988) that activation of PKC may be important in the chemical excitation of nociceptive neurons. Several subtypes of PKC exist that have different patterns of expression in different tissues (Coussens et al., 1986; Parker et al., 1986; Housey et al., 1987; see also Worley et al., 1986). It will be important to determine which subtype(s) is involved in the transmission of nociceptive information for Bk.

\section{References}

Baccaglini, P. T., and Hogan, P. G. (1983) Some rat sensory neurones in culture express characteristics of differentiated pain sensory cells. Proc. Natl. Acad. Sci. USA 80: 594-598.

Batty, I. R., S. R. Nahorski, and R. F. Irvine (1985) Rapid formation of inositol 1,3,4,5-tetrakisphosphate following muscarinic receptor stimulation of rat cerebral cortical slices. Biochem. J. 232: 211-215.

Beck, P. W., and H. O. Handwerker (1974) Bradykinin and serotonin effects on various types of cutaneous nerve fibres. Pfluegers Arch. 347: 209-222.

Beierwaltes, W. H., O. A. Carretero, A. G. Scicli, R. J. Vavrek, and J. M. Stewart (1987) Competitive analog antagonists of bradykinin in the canine hindlimb. Proc. Soc. Exp. Biol. Med. 186: 79-83.

Berridge, M. J. (1983) Rapid accumulation of inositol trisphosphate reveals that agonists hydrolyse polyphosphoinositides instead of phosphatidylinositol. Biochem. J. 212: 849-858.

Berridge, M. J. (1987) Inositol trisphosphate and diacylglycerol: Two interacting second messengers. Annu. Rev. Biochem. 56: 159-195.

Besterman, J. M., V. Duronio, and P. Cuatrecasas (1986) Rapid formation of diacylglycerol from phosphatidylcholine: A pathway for generation of a second messenger. Proc. Natl. Acad. Sci. USA 83: $6785-6789$. 
Bettaney, J., A. Dray, and M. N. Perkins (1988) Protein kinase C activation stimulates afferent $\mathrm{A} \delta$ and $\mathrm{c}$ fibres in neonatal rats in vitro. J. Physiol. (Lond.) 396: 160P.

Braas, K. M., D. C. Manning, D. C. Perry, and S. H. Snyder (1988) Bradykinin analogues: Differential agonist and antagonist activities suggesting multiple receptors. Br. J. Pharmacol. 94: 3-5.

Brown, D. A., and H. Higashida (1988) Inositol 1,4,5-trisphosphate and diacylglycerol mimic bradykinin effects on mouse neuroblastoma $\times$ rat glioma hybrid cells. J. Physiol. (I ond.) 397: 185-207.

Burch, R. M., and J. Axelrod (1987) Dissociation of bradykinin induced prostaglandin formation from phosphatidylinositol turnover in Swiss $3 T 3$ fibroblasts: Evidence for G-protein regulation of phospholipase $A_{2}$. Proc. Natl. Acad. Sci. USA 841: 6374-6379.

Burgess, G. M., J. S. McKinney, R. F. Irvine, and J. W. Putney Jr. (1985) Inositol 1,4,5-trisphosphate and inositol 1,3,4-trisphosphate formation in $\mathrm{Ca}^{2+}$-mobilizing-hormone-activated cells. Biochem. J. 232: 237-243.

Burgess, G. M., M. McNeill, and I. Mullaney (1988) Some actions of bradykinin in rat sensory neurones in culture are mediated by protein kinase C. J. Physiol. (Lond.) 398: 17P.

Burgess, G. M., I. Mullaney, M. McNeill, P. R. Coote, A. Minhas, and J. N. Wood (in press) Activation of guanylate cyclase by bradykinin in rat sensory neurones is mediated by calcium influx: Possible role of the increase in cyclic GMP. J. Neurochem.

Coussens, L., P. J. Parker, L. Rhee, T. L. Yang-Feng, E. Chen, M. D. Waterfield, U. Francke, and A. Ullrich (1986) Multiple, distinct forms of bovine and human protein kinase $\mathrm{C}$ suggest diversity in cellular signaling pathways. Science 233: 859-866.

Derian, C. K., and M. A. Moskowitz (1986) Polyphosphoinositide hydrolysis in endothelial cells and carotid artery segments. J. Biol. Chem. 261: 3831-3837

DeRiemer, S. A., J. A. Strong, K. A. Albert, P. Greengard, and L. K Kaczmarek (1985) Enhancement of calcium current in aplysia neurones by phorbol ester and protein kinase $C$. Nature 314:313-315.

Dichter, M. A., and G. D. Fischbach (1977) The action potential of chick dorsal root ganglion neurones maintained in cell culture. J. Physiol. (Lond.) 267: 281-298.

Di Virgilio, F., T. Pozzan, C. B. Wollheim, L. M. Vicentini, and J. Meldolesi (1986) Tumor promoter phorbol myristate acetate inhibits $\mathrm{Ca}^{2+}$ influx through voltage-gated $\mathrm{Ca}^{2+}$ channels in two secretory cell lines, PCI 2 and RINm5F. J. Biol. Chem. 261: 32-35.

Dolphin, A. C. (1987) Nucleotide binding proteins in signal transduction and disease. TINS 10:53-57.

Downes, C. P., M. C. Mussat, and R. H. Michell (1982) The inositol trisphosphate phosphomonoesterase of the human erythrocyte membrane. Biochem. J. 203: 169-177.

Dray, A., J. Bettaney, P. Forster, and M. N. Perkins (1988) Bradykinininduced stimulation of afferent fibers is mediated through protein kinase C. Neurosci. Lett. 91: 301-307.

Erdos, E. G. (1979) Bradykinin, kallidin and kallikrein. In Handbook of Experimental Pharmacology. Vol. 25, Springer-Verlag, Berlin.

Ewald, D. A., H. J. G. Matthies, T. M. Perney, M. W. Walker, and R. J. Miller (1988a) The effect of down-regulation of protein kinase $C$ on the inhibitory modulation of dorsal root ganglion $\mathrm{Ca}^{2+}$ currents by neuropeptide Y. J. Neurosci. 8: 2447-2552.

Ewald, D. A., P. C. Sternweis, and R. J. Miller (1988b) Guanine nucleotide-binding protein $G_{0}$-induced coupling of ncuropeptide $Y$ receptors to $\mathrm{Ca}^{2+}$ channels in sensory neurons. Proc. Natl. Acad. Sci. USA $85: 3633-3637$.

Francel, P. C., R. J. Miller, and G. Dawson (1987) Modulation of bradykinin-induced inositol trisphosphate release in a novel neuroblastoma $\times$ dorsal root ganglion sensory neuron cell line (F-11). J. Neurochem. 48: 1632-1639.

Franze, M., and S. Mense (1975) Muscle receptors with group IV afferent fibres responding to application of bradykinin. Brain Res. 92, 369-383

Galizzi, J.-P., J. Qar, M. Fosset, C. Van Renterghem, and M. Lazdunski (1987) Regulation of calcium channels in aortic muscle cells by protein kinase $\mathrm{C}$ activators (diacylglycerol and phorbol esters) and by peptides (vasopressin and bombesin) that stimulate phosphoinositide brcakdown. J. Biol. Chem. 262: 6947-6950.

Gallego, R., and C. Eyzaguirre (1978) Membrane and action potential characteristics of $\mathrm{A}$ and $\mathrm{C}$ nodose ganglion cells studied in whole ganglia and tissue slices. J. Neurophysiol. 4I: 1217-1232.

Girard, P. R., C. J. Mazzei, and J. F. Kuo (1986) Immunological quantitation of phospholipid/ $\mathrm{Ca}^{2+}$-dependent protein kinase and its fragments. J. Biol. Chem. 261: 370-375.

Griendling, K. K., P. Delafontaine, S. E. Rittenhouse, M. A. Gimbrone, Jr., and K. W. Alexander (1987) Correlation of receptor sequestration with sustained diacylglycerol accumulation in angiotensin IIstimulated cultured vascular smooth muscle cells. J. Biol. Chem. 262: 14555-14562.

Gorke, K., and F.-K. Pierau (1980) Spike potentials and membrane properties of dorsal root ganglion cells in pigeons. Pfluegers Arch. 386: $21-28$.

Hamill, O. P., A. Marty, E. Neher, B. Sakmann, and F. Sigworth (1981) Improved patch-clamp techniques for high-resolution current recording from cells and cell-free membrane patches. Pfluegers Arch. 391: 85-100.

Harper, A. A., and S. N. Lawson (1985a) Conduction velocity is related to morphological cell type in rat dorsal root ganglion neurones. J. Neurophysiol. 359: 31-46.

Harper, A. A., and S. N. Lawson (1985b) Electrical properties of rat dorsal root ganglion neurones with different peripheral nerve conduction velocities. J. Physiol. (Lond.) 359: 47-63.

Heslop, J. P., R. F. Irvine, A. H. Tashijan, Jr., and N. J. Berridge (1985) Inositol tetrakis- and pentakisphosphates in $\mathrm{GH}_{4}$ cells. J. Exp. Biol. 119: 395-402.

Higashi, H., N. Ueda, S. Nishi, J. P. Gallagher, and P. Shinick-Gallagher (1982) Chemorereceptors for serotonin (5HT), acetylcholine (Ach), bradykinin (Bk) and gamma-aminobutyric acid (GABA) on rabbit visceral afferent neurones. Brain Res. Bull. 8: 23-32.

Higashida, H., and D. A. Brown (1986) Two polyphosphatidylinositide metabolites control two $\mathrm{K}^{+}$currents in a neuronal cell. Nature 323: 333-335.

Higashida, H., R. A. Streaty, W. Klee, and M. Nirenberg (1986) Bradykinin-activated transmembrane signals are coupled via $\mathrm{N}_{o}$ or $\mathrm{N}_{i}$ to production of inositol 1,4,5-trisphosphate, a second messenger in NG108-15 neuroblastoma-glioma hybrid cells. Proc. Natl. Acad. Sci. USA 83: 942-946.

Holz, G. G. IV, S. G. Rane, and K. Dunlap (1986) GTP-binding proteins mediate transmitter inhibition of voltage-dependent calcium channels. Nature 319: 670-672.

Housey, G. M., C. A. O'Brian, M. D. Johnson, P. Kirschmeier, and I. B. Weinstein (1987) Isolation of cDNA clones encoding protein kinase C: Evidence for a protein kinase C-related gene family. Proc. Natl. Acad. Sci. USA 84: 1065-1069.

Ikeda, S. R., G. G. Scofield, and F. F. Weight (1986) $\mathrm{Na}^{+}$and $\mathrm{Ca}$ currents of acutely isolated rat nodose ganglion cells. J. Neurophysiol. 55: 527-539.

Imai, A., and M. C. Gershengorn (1986) Phosphatidylinositol 4,5bisphosphate turnover is transient while phosphatidylinositol turnover is persistent in thyrotropin-releasing hormone-stimulated rat pituitary cells. Proc. Natl. Acad. Sci. USA 83: 8540-8544.

Irvine, R. F., A. J. Letcher, and R. M. C. Dawson (1984a) Phosphatidylinositol-4,5-bisphosphate phosphodiesterase and phosphomonoesterase activities of rat brain. Biochem. J. 218: 177-185.

Irvine, R. F., A. J. Letcher, D. J. Lander, and C. P. Downes (1984b) Inositol trisphosphates in carbachol stimulated rat parotid glands. Biochem. J. 223: 237-243.

Irvine, R. F., A. J. Letcher, J. P. Heslop, and M. J. Berridge (1986) The inositol tris/tctrakisphosphatc pathway-Demonstration of Ins $(1,4,5) \mathrm{P}_{3} 3$-kinase activity in animal tissues. Nature 320:631-634.

Irving, H. R., and J. H. Exton (1987) Phosphatidylcholine breakdown in rat liver plasma membranes. J. Biol. Chem. 262: 3440-3443.

Jackson, T. R., T. J. Hallam, C. P. Downes, and M. R. Hanley (1987) Receptor coupled events in bradykinin action: Rapid production of inositol phosphates and regulation of cytosolic free $\mathrm{Ca}^{2+}$ in a neural cell line. EMBO J. 6: 49-54.

Kaczmarek, L. K. (1987) The role of protein kinase $C$ in the regulation of ion channels and neurotransmitter release. TINS 10:30-34.

Kameyama, M. (1983) Ionic currents in cultured dorsal root cells from adult guinea pigs. J. Membrane Biol. 72: 195-203.

Leeb-Lundberg, F., S. Cotecchia, J. W. Lomasney, J. F. DeBernardis, R. J. Lefkowitz, and M. G. Caron (1985) Phorbol esters promote $\alpha_{1}$-adrenergic receptor phosphorylation and receptor uncoupling from inositol phospholipid metabolism. Proc. Natl. Acad. Sci. USA 82: $5651-5655$.

Liles, W. C., D. D. Hunter, K. E. Meier, and N. M. Nathanson (1986) Activation of protein kinase $\mathrm{C}$ induces rapid internalization and sub- 
sequent degradation of muscarinic acetylcholine receptors in neuroblastoma cells. J. Biol. Chem. 261: 5307-5313.

Lindsay, R. M., and H. P. Rang (1988) Activation of protein kinase $\mathrm{C}$ causes an inward current in a proportion of rat sensory neurones in culture. J. Physiol. (Lond.) 398: 16P.

Mayer, M. L. (1985) A calcium-activated chloride current generates the after-depolarisation of rat sensory neurones in culture. J. Physiol. (Lond.) 364: 217-239.

Mense, S., and R. F. Schmidt (1974) Activation of group IV afferent units from muscle by algesic agents. Brain Res. 72: 305-310.

Miller, R. J. (1987) Bradykinin highlights the role of phospholipid metabolism in the control of nerve excitability. Trends Neurosci. 10: 226-228.

Nishizuka, Y. (1988) The molecular heterogeneity of protein kinase $\mathrm{C}$ and its implications for cellular recognition. Nature 334: 661-665.

Osugi, T., T. Imaizumi, A. Mizushima, S. Uchida, and H. Yoshida (1986) l-oleoyl-2-acetyl-glycerol and phorbol diester stimulate $\mathrm{Ca}^{2+}$ influx through $\mathrm{Ca}^{2+}$ channels in neuroblastoma $\times$ glioma hybrid NG108-15 cells. Eur. J. Pharmacol. 126:47-51.

Osugi, T., T. Imaizumi, A. Mizushima, S. Uchida, and II. Yoshida (1987) Phorbol ester inhibits bradykinin-stimulated inositol trisphosphate formation and calcium mobilization in neuroblastoma $\times$ glioma hybrid NG108-15 cells. J. Pharamcol. Exp. Ther. 240: 617622.

Parker, P. J., L. Coussens, N. Totty, L. Rhee, S. Young, E. Chen, S. Stabel, M. D. Waterfield, and A. Ullrich (1986) The complete primary structure of protein kinase $\mathrm{C}-$ The major phorbol ester receptor. Science 233: 853-859.

Perney, T. M., L. D. Hiring, S. E. Leeman, and R. J. Miller (1986) Multiple calcium channels mediate neurotransmitter release from peripheral neurons. Proc. Natl. Acad. Sci. USA 83: 6656-6659.

Piomelli, D., A. Volterra, N. Dale, S. A. Siegelbaum, E. R. Kandel, J. H. Scwartz, and F. Belardetti (1987) Lipoxygenase metabolites of arachidonic acid as second messengers for presynaptic inhibition of Aplysia sensory cells. Nature 328: 38-43.

Rane, S. G., and K. Dunlap (1986) Kinase C activator 1,2-oleoylacetylglycerol attenuates voltage-dependent calcium current in sensory neurons. Proc. Natl. Acad. Sci. USA 83: 184-188.

Rang, H. P., and M. Ritchie (1988) Depolarization of nonmyelinated fibers of the rat vagus nerve produced by activation of protein kinase C. J. Neurosci. 8: 2606-2617.

Regoli, D., G. Drapeau, P. Rovero, S. Dion, P. D'Orleans-Juste, and J. Barabe (1986) The actions of kinin antagonists on $B_{1}$ and $B_{2}$ receptor systems. Eur. J. Pharmacol. 123: 61-65.

Scott, R. H., and A. C. Dolphin (1987) Activation of a $G$ protein promotes agonist responses to calcium channel ligands. Nature 330 : $760-762$.

Sha'affi, R. I. and P. H. Naccache (1985) Relationship between calcium, arachidonic acid metabolites and neutrophil activation. In $\mathrm{Cal}$ cium in Biological Systems, R. P. Rubin, G. B. Weiss, and J. W. Putney, Jr., eds., pp. 137-146, Plenum, New York.

Sperti, G., and W. S. Colucci (1987) Phorbol ester-stimulated bidirectional transmembrane calcium flux in $\mathrm{A}_{-} \mathrm{r}_{5}$ vascular smooth muscle cells. Mol. Pharmacol. 32: 37-42.

Steranka, L. R., D. C. Manning, C. J. DeHaas, J. W. Ferkany, S. A. Borosky, J. R. Connor, R. J. Vavrek, J. M. Stewart, and S. A. Snyder (1988) Bradykinin as a pain mediator: Receptors are localised to sensory neurones and antagonists have analgesic actions. Proc. Natl. Acad. Sci. USA 85: 3245-3249.

Stewart, J. N., and R. J. Vavrek. (1987) Bradykinin competitive antagonists: Design and activities. In Enzyme and Enzyme Inhibitors, R. L. Schowen and A. Barth, eds., Pergamon, Oxford, UK.

Storry, J. E., and B. Tuckley (1967) Thin layer chromatography of plasma lipids by single development. Lipids 2: 501-502.

Tamaoki, T., H. Nomoto, I. Takahashi, Y. Kato, M. Morimoto, and F. Tomita (1986) Staurosporine, a potent inhibitor of phospholipid/ $\mathrm{Ca}^{2+}$ dependent protein kinase. Biochem. Biophys. Res. Commun. 135: 397-402.

Tertoolen, L. G., B. C. Tilly, R. F. Irvine, and W. H. Moolenaar (1987) Electrophysiological responses to bradykinin and micro-injected inositol phosphates in neuroblastoma cells. FEBS Lett. 214: 365-369.

Thayer, S. T., T. M. Perney, and R. J. Miller (1988) Regulation of calcium homeostasis in sensory neurones by bradykinin. J. Neurosci. 8: 4089-4097.

Vincentini, L. M., F. Di Virgilio, A. Ambrosini, T. Pozzan, and J. Meldolesi (1985) Tumor promoter phorbol 12-myristate, 13-acetate inhibits phosphoinositide hydrolysis and cytosolic $\mathrm{Ca}^{2+}$ rise induced by the activation of muscarinic receptors in PC12 cells. Biochem. Biophys. Res. Commun. 127: 310-317.

Watson, S. P., and E. G. Lapetina (1985) 1,2-diacylglycerol and phorbol ester inhibit agonist-induced formation of inositol phosphates in human platelets: Possible implications for negative feedback regulation of inositol phospholipid hydrolysis. Proc. Natl. Acad. Sci. USA 82: $2623-2626$

Weinreich, D. (1986) Bradykinin inhibits a slow spike afterhyperpolarisation in visceral sensory neurones. Eur. J. Pharmacol. 132: 6163.

Whalley, E. T., S. Clegg, J. M. Stewart, and R. J. Vavrek (1987) The effect of kinin agonists and antagonists on the pain response of the human blister base. Naunyn-Schmiedeberg's Arch. Pharmacol. 336: 652-655

Wood, J. N., J. Winter, I. F. James, H. P. Rang, J. Yeats, and S. J. Bevan (1988) Capsaicin-induced ion fluxes in dorsal root ganglion cells in culture. J. Neurosci. 8: 3208-3220.

Worley, P. F., J. M. Baraban, and S. H. Snyder (1986) Heterogenous localization of protein kinase $\mathrm{C}$ in rat brain: Autoradiographic analysis of phorbol ester receptor binding. J. Neurosci. 6: 199-207.

Yano, K., H. Higashida, R. Inoue, and Y. Nozawa (1984) Bradykinininduced rapid breakdown of phosphatidylinositol 4,5 bisphosphate in neuroblastoma $\times$ glioma hybrid NG108-15 cells. J. Biol. Chem. 259: 10201-10207.

Yano, K., H. Higashida, H. Hattori, and Y. Nozawa (1985) Bradykinin-induced transient accumulation of inositol tris-phosphate in neuron-like cell line NG108-15 cells. FEBS Lett. 181: 403-406.

Yoshida, S., Y. Matsuda, and A. Samejima (1978) Tetrodotoxin-resistant sodium and calcium components of action potentials in dorsal root ganglion cells of the adult mouse. J. Neurophysiol. 41: 10961106.

Young, S., P. J. Parker, A. Ullrich, and S. Stabel (1987) Down-regulation of protein kinase $\mathrm{C}$ is due to an increased rate of degradation. Biochem. J. 244: 775-779. 